Review Article

\title{
Developments in Platinum-Group Metals as Dual Antibacterial and Anticancer Agents
}

\author{
Ayodele T. Odularu $\left(\mathbb{D},{ }^{1}\right.$ Peter A. Ajibade $\mathbb{D}^{2},{ }^{2}$ Johannes Z. Mbese $\mathbb{D}^{1},{ }^{1}$ \\ and Opeoluwa O. Oyedeji ${ }^{1}$ \\ ${ }^{1}$ Department of Chemistry, University of Fort Hare, Private Bag X1314, Alice 5700, South Africa \\ ${ }^{2}$ School of Chemistry and Physics, University of KwaZulu-Natal, Pietermaritzburg Campus, Scottsville 3209, South Africa \\ Correspondence should be addressed to Ayodele T. Odularu; 201106223@ufh.ac.za
}

Received 8 May 2019; Accepted 10 June 2019; Published 6 November 2019

Academic Editor: Liviu Mitu

Copyright ( 2019 Ayodele T. Odularu et al. This is an open access article distributed under the Creative Commons Attribution License, which permits unrestricted use, distribution, and reproduction in any medium, provided the original work is properly cited.

\begin{abstract}
Platinum-group (PG) complexes have been used as antibacterial and anticancer agents since the discovery of cisplatin. The science world still requires improvement on these complexes because of multidrug and antineoplastic resistances. This review observes discoverers and history of these platinum-group metals (PGMs), as well as their beneficial applications. The focus of this study was biological applications of PGMs in relation to human health. Sandwich and half-sandwich PGM coordination compounds and their metal nanoparticles give improved results for biological activities by enhancing efficient delivery of both antibacterial and anticancer drugs, as well as luminescent bioimaging (biomarkers) for biological identifications.
\end{abstract}

\section{Introduction}

According to McQuitty, Ellahioui et al., Marques, and Rajini et al., many years ago, metals were considered for medicinal uses to treat diseases [1-4]. In order to enhance the activities of these metals, new developments in modern medicine are recognized and confirmed because of the high efficiencies of various metal-based drugs to overcome the drawbacks of metals on different diseases, such as bacteria and cancer $[1,2]$. Cancer is rated the second most affecting disease in humans globally after cardiovascular diseases [3]. On another note, resistance to antibiotics is a threat to public health against eliminating bacterial infections [51]. In controlling these diseases and circumventing the drawbacks experienced in the use of organic-based drugs, d-block metals called transition metals possess unique electronic structures, which enable them to be versatile by modifying the properties of a certain molecule [1]. Among these transition metals are platinum-group metals (PGMs). They are a group of six transition d-block metallic elements clustered together in the periodic table. These PGMs are iridium, osmium, palladium, platinum, rhodium, and ruthenium. They are also called platidises, platinides, platinoids, platinum family, platinum group, platinum metals, or platinum-group elements (PGEs). They possess similar physical and chemical characteristics and have propensity to be in the same mineral ores' deposits. In addition, there is a subclassification into the iridium-group platinum-group elements (IPGEs: Ir, Os, and Ru) and the palladium-group platinum-group elements (PPGEs: $\mathrm{Rh}, \mathrm{Pd}$, and $\mathrm{Pt}$ ) on the basis of their performances in geological systems. The PGMs coordination compounds belong to conventional chemotherapy (single and combination therapy), as well as complementary and alternative medicine (CAM). Multiple drug resistance, adverse side effects, little therapeutic indices, high-dose requirements, reduced bioavailability, and nonspecific cell/organ targeting are some of the drawbacks of conventional chemotherapy and CAM, which brought in a pause in progress and success [6]. These drawbacks warrant an urgent need to design and develop chemotherapy which can target the bacterial and cancerous cells. In this manner, it will control the drawbacks and at the same time increase the therapeutic effectiveness. Chemists are using novel ways to improve delivery methods in the field of metallodrugs with 
new developments and modifications of existing drugs. Many yeas ago till today, multipurpose materials, such as bio-macromolecular scaffolds, inorganic carriers, lipids, polymers, and polymeric hydrogels, have been used to deliver chemotherapeutics to targeted cancer cells with enhanced effectiveness. Additionally, in the last twenty years, nanotechnology emergence has made positive impacts on clinical therapeutics [6-9]. Nanomedicine, a division of nanotechnology, entails the use of nanoscale drug carriers, which have potentials to overcome these drawbacks by enhancing therapeutic effectiveness through active cellular uptake and reduced toxicity, and help to improve permeability and retention. These nanocarriers containing chemotherapeutics achieve their aims when used in combination with molecules which bind to overexpressed antigens [6]. Presently, some nanoparticles-based chemotherapeutics are clinically endorsed; others are in numerous preclinical and clinical stages. Nevertheless, nanocarriers have many merits as drug carrier systems, but lack of biodegradation, reduced bioavailability, unstable circulation, insufficient tissue distribution, and possible toxicity are challenges over the safety, most especially when it comes to long administration. This study aimed to explore the history of PGMs, general uses, and extensive biological relevance of PGMs with their nanoparticles to human health.

\section{The PGMs}

All six PGMs (iridium, osmium, palladium, platinum, rhodium, and ruthenium) are reviewed to obtain the significance of this study.

2.1. Iridium. Between 1803 and 1804, Smithson Tennant, a British chemist, discovered iridium in the dregs of crude platinum when it was dissolved using aqua regia (hydrochloric acid and trioxonitrate(V) acid) [10-13]. The origin of the name was derived from the Latin word, "iris," which means, "rainbow." Iridium is a d-block transition metal with a symbol of Ir, atomic number of 77, and atomic mass of 192.217 [11]. Iridium has variable oxidation states from -III to +IX [14], but according to Liu et al, iridium has four different oxidation states, namely, $+1,+2,+3$, and +4 . [15]. The main coordination numbers are 4 and 6 [15]. It forms organoiridium coordination compounds. Liu et al. stated that the inert and stable nature of iridium(III) could be appropriate characteristics for drug design. $\mathrm{Ir}^{\mathrm{III}}$ has a more stable oxidation than $\operatorname{Ir}^{\mathrm{I}}$ with a higher oxidation number, which helps to provide broad basic variety from a wide range of ligands [15]. With regards to the relevance of ligands in targeting site, the characteristics of $\mathrm{Ir}^{\mathrm{III}}$ enable their coordination compounds to attain its target site devoid of modifications. Due to instability of $\operatorname{Ir}(\mathrm{III})$ complexes with benzene ligands, they bind alternatively with cyclopentadienyl ligands. Iridium is the first member of the platinum-group metals (PGMs). It is hard and a brittle white solid with a yellowish tinge. In addition, it is one of the densest metals and most corrosive opposing metal ever known [10]. Iridium's industrial production is from the by product of nickel and copper mining and development. Iridium has various industrial applications as a platinum hardener for electrical contacts, for coating optical lenses to promote clear vision, and an alloy with osmium to produce fountain pens and compass bearings [7]. Pharmaceuticals focusing on metal complexes of iridium are still at the early stages [8]. Chen et al. used the existing antidiabetic drug called biguanide ( $\mathrm{N}, \mathrm{N}$ donor ligand) to ligate iridium(III) ion to obtain iridium.(III) biguanide coordination compounds [16]. These complexes were used as potent antimicrobial agents because biguanides were inactive when administered alone. Medically, organometallic complexes of iridium(III) from research proved to have potentials for anticancer and antimicrobial activities [15-25]. In recent times, organoiridium(III) complexes showed potentials as anticancer agents. Among the most inert low-spin $\mathrm{d}_{6}$ metallic ions is Ir(III), since inertness and stability are essential properties for drug design and development [11]. Lu et al. reported the antibacterial and anticancer activities of some cyclometalated iridium(III) complexes [17].

On the other hand, sandwich and half-sandwich complexes are arene metal complexes which are well recognized classes of organometallic compounds [26]. A sandwich compound has a metal between two arene ligands bound by haptic covalent bonds, while half-sandwich compound has a polyhapto ligand bond to an MLn centre, where $\mathrm{L}$ is a unidentate ligand. Unidentate ligands used are mostly halides.

Adhikari et al. studied half-sandwich $\mathrm{d}^{6}$ metal complexes (iridium, rhodium, and ruthenium(II)) comprising 2substituted-1,8-napthyridine ligands with unexpected bonding modes (Figure 1). The results gave less active compounds than cisplatin (standard drug). On a similar but better note, Štarha et al. used half-sandwich Ir(III) complex of N1-pyridyl-7-azaindole as an anticancer agent, which exceeds the cytotoxicity of cisplatin at various human cancer cells and 3D multicellular tumour spheroids [27]. Likewise, Hearn et al. used new action mechanisms of organometallic iridium(III) complexes to obtain better anticancer activities than cisplatin against ovarian carcinoma cells (A2780) [28]. They used cyclopentadienyl ligands containing $\mathrm{N}, \mathrm{N}$ or $\mathrm{C}$, $\mathrm{N}$-chelates occupying the fourth and fifth sites and a monodentate chlorine ligand as the sixth site to synthesize four half-sandwich organometallic $\mathrm{Ir}^{\mathrm{III}}$ cyclopendienyl pseudo-octahedral complexes as effective cytostatic and cytotoxic anticancer agents. Lu et al. used some cyclometalated iridium(III) complexes as dual antibacterial and anticancer agent. Lu et al. cited the work of Mukherjee et al., in which three cyclometalated iridium(III) coordination compounds containing functionalized dithiocarbamates possessed dual anticancer and anticancer activities due to delocalised $\pi$ electrons directly above the chelate ring. $\mathrm{Lu}$ et al. based their research on four iridium(III) coordination compounds and one rhodium(III) coordination compound against two human ovarian carcinoma cells (A2780 and SKOV3), two melanoma (skin) cell lines (A375 and A2058), one cervical cell line (HeLa), one hepatocarcinoma (liver) cell line (HepG2), and four bacterial strains (Enterococcus faecalis, Escherichia coli, Klebsiella pneumoniae, and 


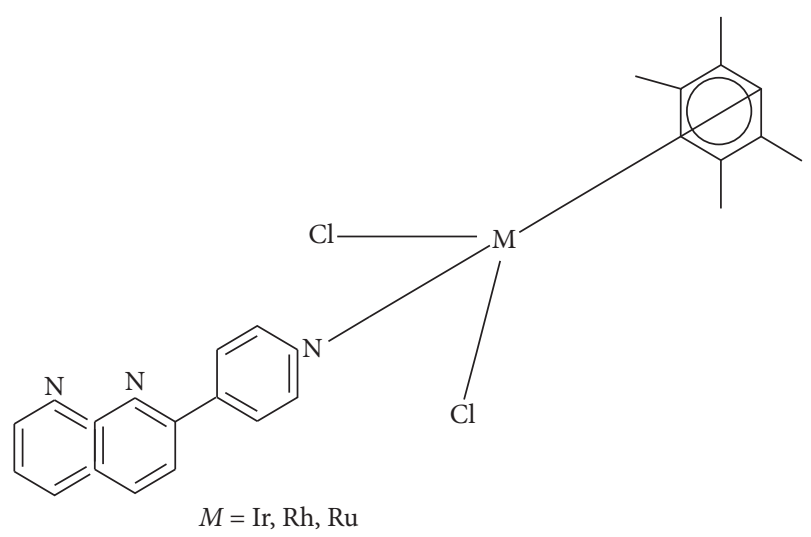

Figure 1: Half-sandwich $\mathrm{d}^{6}$ metal complexes comprising 2substituted 1, 8-napthyridine ligands with unexpected bonding modes.

Staphylococcus aureus). Lu et al. concluded from their studies that the first synthesized iridium(III) complex consisting of 2-(p-tolyl)pyridine had a lower cyclometalated ligand compared to quinolone or isoquinoline-based cyclometalated ligands of complexes 2 and 4 correspondingly resulting to its highest antibacterial activities. They got higher bacterial activity in terms of higher zone of inhibition when iridium was replaced with rhodium in complex 5. On another note, an amino substituent on the phenanthroline ligand made the first iridium(III) coordination compound a superior anticancer agent than other studied complexes with the exception of HepG2. In comparison, while Mukherjee et al. used sulphur-nitrogen (S-N) donor ligands, Lu et al. used nitrogen-nitrogen (N-N) donor ligands to ligate iridium(III) ions. Lu et al.'s molecular structures for cyclometalated iridium(III) complexes and rhodium(III) complex are shown in Figure 2 [17].

Lucas et al. synthesized four iridium and one ruthenium arene complexes with $(\mathrm{N}, \mathrm{N}),(\mathrm{N}, \mathrm{O})$, and $(\mathrm{O}, \mathrm{O})$ coordination modes from different ligands. The cytotoxicity potency trend gave $(\mathrm{N}, \mathrm{O})>(\mathrm{O}, \mathrm{O})>(\mathrm{N}, \mathrm{N})$ for the five synthesized coordination compounds. Thy discovered that the activities of $(\mathrm{N}, \mathrm{O})$ piano-stool coordination compounds are the most effective to be compared with cisplatin based on precision. They discovered that $(\mathrm{N}-\mathrm{O})$ complexes were more effective when compared to cisplatin. Among the five synthesized compounds, the chemical structure of ketoiminate complex is as shown in Figure 3. In summary, among the three groups of aforementioned researchers for iridium(III) complexes, Lucas et al.'s results for cytotoxic activities were very precise with cisplatin against HT-29 (colon) and (MCF-7) breast cancer cell lines. The constancy in all the donor ligands is the presence of nitrogen.

$\mathrm{Ma}$ et al. stated that bioimaging is the application of microscopes or scanners for cell, tissue, organ, and organism visualization. They further said that it supports the study of biological processes, clarifies the nature of signalling and connections at a cellular and molecular level, and arrests the drive of cellular molecules. Additionally, bioimaging can trace metabolites that, when used as biomarkers, aid in disease identification and treatment reaction. In order to produce high-quality images for biological monitoring, magnetic resonance, optical signals, and ultrasound have been employed [29]. Qualities such as ability for long-term observing of a single sample, low cost, high detection sensitivity, and speedy response have speeded up the uses of bioimaging in recent years. Among the luminescent transition metal complexes which possess advantages as bioimaging reagents are iridium(III) complexes [29]. These qualities are (i) high room temperature quantum yields, (ii) high photochemical and physicochemical stabilities, (iii) large Stokes shifts which lower the excitation beam and inner filter effects, (iv) long phosphorescence emission lifetimes which lower the interference of autofluorescence by the application of time-gated imaging techniques, (v) multichromophoric structures potentially allowing dual emission under single wavelength excitation, (vi) spherical molecular shape to lower harmful intermolecular impacts, such as aggregation, (vii) structural flexibility which enables preparation of coordinated saturated or unsaturated complexes, (viii) synthetic flexibility for fine-tuning photophysical property, and (ix) tunable phosphorescence emission spectra, to the extent of reaching the near-infrared region.

Ma et al. introduced concept of nanoparticles, whereby iridium(III) complex-assisted nanoparticles were used for biological applications [29].

An application of bioimaging is bioanalytical labelling, which has made nanomaterials enjoy remarkable growth. As a result, luminescent nanoparticles (NPs) have been used widely in the biological and medical fields, such as assembled molecular control, biological therapeutics, disease diagnostics, drug delivery, genomic studies, pharmaceutical screening, protein purification, and proteomic studies. Iridium(III) complexes are good precursors, which support nanomaterials for luminescent sensing, highlighting those which can be used for intracellular imaging. In addition, combination of iridium(III) complexes with nanomaterials, such as inorganic NPs, polymer NPs, upconversion NPs, and quantum dots, has contributed to the fields of drug delivery, intracellular sensing, and photodynamic therapy. In specific, the combination of iridium(III) complexes with several NPs might enhance a variety of their properties, such as aqueous solubility, cellular distribution, cytotoxicity, and uptake efficiency, in order to improve bioimaging applications [29].

2.2. Osmium. Likewise, between 1803 and 1804, Smithson Tennant also discovered osmium, whose name has a Greek origin, "osmic," which means smell, scent, or odour [10, 13]. The discovery of osmium was linked with platinum, due to the fact that osmium was the black residue which remained after the dissolution of platinum in aqua regia $[10,13]$. According to Arbiaster, it is the densest element at all temperatures and ambient pressure [30]. It is a bluish white, hard, and lustrous metal which is solid at room temperature. It exists in nature both as a free element and in combined state with copper and nickel as alloys. The major source of extraction is a by-product of refinery of copper and nickel. Osmium is found in the mineral of iridosule, as well as in platinum-bearing river sands in North America, South 


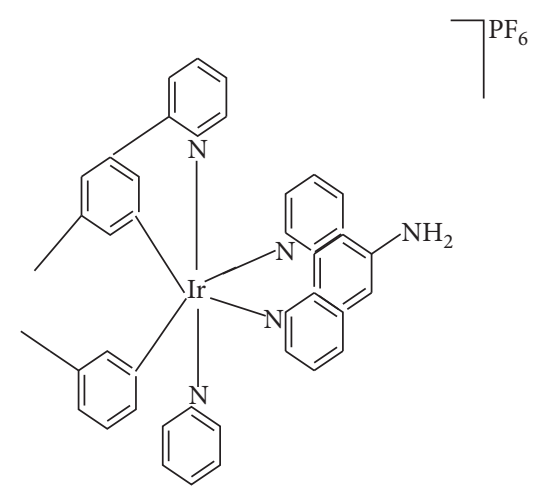

(a)

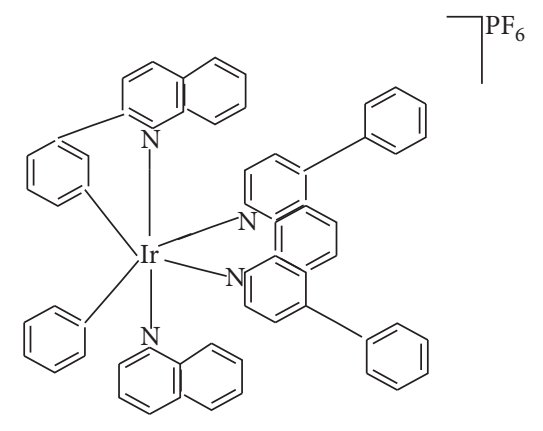

(c)

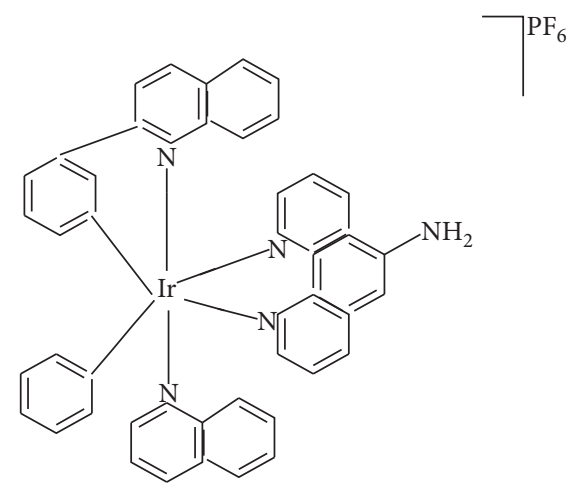

(b)

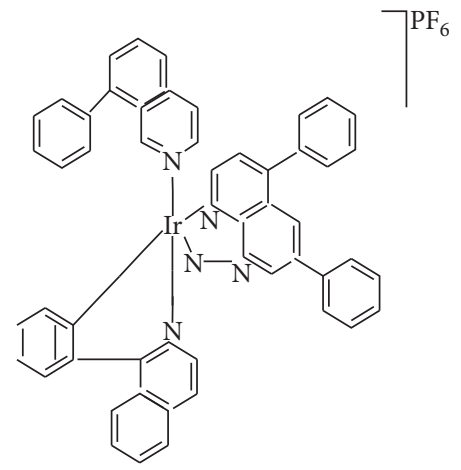

(d)

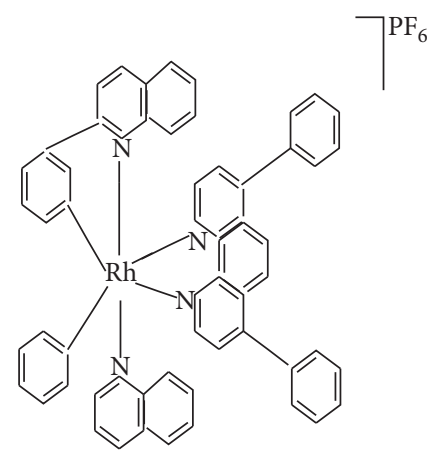

(e)

FIgUre 2: Molecular structure of cyclometalated iridium(III) complexes (a-d) and cyclometalated iridium(III) complex (e).

America, and Urals. Osmium has variable oxidation states of $+3,+4,+6$, and +8 , but sometimes $0,+1,+2,+5$, and +7 . Osmium is a transition metal, a PGM with an atomic number of 76 and a mass number of 190.23. It has an electronic configuration of $[\mathrm{Xe}] 4 \mathrm{f}^{14} 5 \mathrm{~d}^{6} 6 \mathrm{~s}^{2}$. The assumption that osmium is very toxic and volatile makes the pure form to be hardly used [31]. For industrial application, osmium is used as alloys when mixed with other metals due to its high tolerance to corrosion and wearing. Osmium is also found useful in the technology of light bulb. Instruments such as electrical contacts, phonograph needles, and pivots are produced from alloys of osmium [30]. The natural combination with iridium is used to make fountain pen tips. Osmium tetroxide, though a very strong, toxic oxidant, is useful for detecting fingerprints and stain fatty tissues for microscope slides. Medically, osmium complexes of valences II and VI are used as anticancer and antimicrobial agents
[32-43]. Štarha et al.'s synthesized half-sandwich Os(II) complex $\left(\left[\mathrm{Os}\left(\mathrm{n}^{6}-\mathrm{pcym}\right)\right.\right.$ (bphen) $\left.\left.(\mathrm{dca})\right] \mathrm{PF}_{6}\right)$ as shown in Figure 4 exhibited good in vitro cytotoxity against A2780 human ovarian carcinoma cells, slightly above cisplatin [44]. In the case of Fu et al., they synthesized two chloro and two iodido (four) chiral Os(II) arene anticancer complexes [45]. The four Os(II) coordination compounds are shown in Figure 5. The two iodido complexes showed higher anticancer activities (lesser inhibition concentration (IC) values) to A2780 human ovarian cancer cells than cisplatin and were more active than the two chlorido derivatives. Similarly, Romero-Canelón et al. stated that organometallic halfsandwich $\left[M(p \text {-cymene) (azo/imino-pyridine) } X]^{+}\right.$, where $M=\mathrm{Ru}(\mathrm{II})$ or OsII and $X=\mathrm{Cl}$ or I, showed potent antiproliferative action toward a range of cancer cells. Here, iodide complexes are also more effective than the chloro analogues, but not cross-resistant to cisplatin and oxaliplatin 


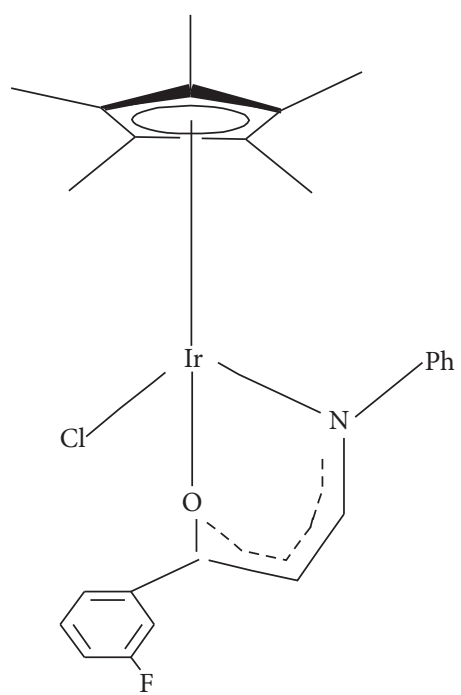

Figure 3: Iridium(III) ketoiminate complex.

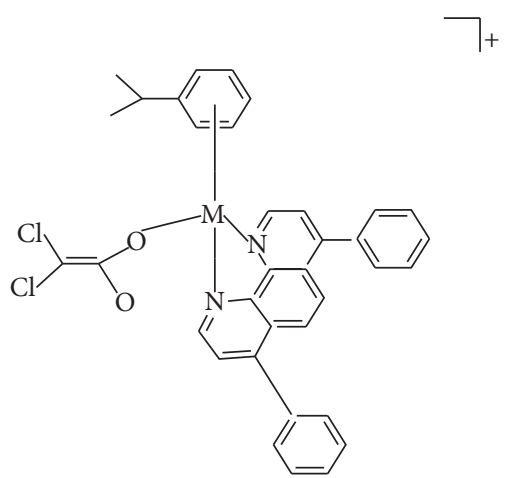

FIGURE 4: Synthesized half-sandwich Os(II) complex ([M( $\mathrm{\eta}^{6}$-ocym) (bphen) (dca) $\mathrm{PF}_{6}$ ).

[46]. Štarha et al.'s study focused on nitrogen-oxygen donor ligands, while Romero-Canelón et al.'s study focused on the use of nitrogen-nitrogen donor ligands. Additionally, Zhang and Sadler synthesized organometallic osmium(II) compounds and reported that Os(II) arene complexes with guaranteed phenylazopyridine ligands (nitrogen-nitrogen donor ligands) were more effective and inert to iodide as the unidentate ligand [47]. One of the arene structures is shown in Figure 6. They further stated that they were not only more effective than cisplatin in the NCI-60 cell line but also fortynine times more effective on average in a Sanger plan of 809 cancer cell lines and active in vivo. The Os(II/III) anticancer agents designed previously as analogues of $\mathrm{Ru}(\mathrm{II} / \mathrm{III})$ complexes are Os-RAPTA-C, Os-RM175, and Os-NAMI-A [48]. In recent times, organometallic arene Os(II) azopyridine complex FY26 exhibits high anticancer activity and mechanism of reaction (Figure 7). Arene Os(II) azopyridine complex FY26 is a prodrug, which has the ability to be activated catalytically by cellular glutathione (GSH) and increases the level of intracellular reactive oxygen species (ROS) in cancer cells extensively [48]. Gichumbia et al. synthesized three half-sandwich Os(II) complexes, $\left[\left(\eta^{6}-\right.\right.$ benzene) $\left.\mathrm{OsCl}\left(\mathrm{C}_{5} \mathrm{H}_{4} \mathrm{~N}-2-\mathrm{CH}=\mathrm{N}-\mathrm{C}_{6} \mathrm{H}_{5} \mathrm{X}\right)\right] \quad$ (where $X=p$ -
$\left.\mathrm{F}(1), p-\mathrm{Cl}(2), p-\mathrm{CH}_{3}\left(\mathrm{PF}_{6}\right)\right)$, as shown in Figure 8. In vitro tests were carried out on the complexes against Caco-2 (human epithelial colorectal adenocarcinoma), HepG2 (human heptocellular carcinoma), and MCF-7 (human breast adenocarcinoma) tumour cell lines, and HE293 (human kidney) nontumour cell line. Complex 2, the most antiproliferative complex, with $\mathrm{Cl}$ and its pyridyl-imine ligand (4-(chlorophenyl)-pyridin-2-yl-methylene amine), was able to undergo antibacterial screening against selected Gram-negative and Gram-positive bacterial strains, such as drug resistant Enterococcus faecalis and methicillin-resistant Staphylococcus aureus ATCC 43300. It showed moderate activities. In essence, complex 2 is a dual prospective antibacterial and potent anticancer agent [49]. Comparing the halide substituents, Zhang and Huang reported that chlorido and iodido functionalized coordination compounds were potent similarly, while the bromido analogues yielded the least active compounds in vitro [48]. Additionally, they stated the luminescent bioimaging properties of Os(III) complexes [48]. All the aforementioned researchers used nitrogen-nitrogen donor ligands which all show their higher potencies when compared with cisplatin and their effectiveness as antibacterial agents. According to Zhang and Huang polypyridyl Os(II) coordination compounds have prospective advantages in luminescent cell imaging and photodynamic therapy because of their good photophysical and photochemical characteristics, such as high photostability, long-wavelength metal-ligand charge transfer (MLCT), and near-infrared (NIR) emission [48].

2.3. Palladium. In 1802, William Hyde Wollaston discovered palladium, but due to a controversy which arose, the credit of discovery was given to Richard Chenevix [50]. The origin of the name came from Pallas (Greek goddess of wisdom), a name given to an asteroid. It is mined from ores of copper, mercury, nickel, and platinum. It is a transition metal, as well as a PGM, with a symbol of Pd, atomic number of 46 , and atomic mass of 106 . It is a white solid with a cubic crystal structure. Palladium is the least dense metal in the platinum group. The leading producers of palladium which manufacture about $40 \%$ of the yearly supply worldwide are Russia and South Africa. The industrial applications involve automobile catalytic converters because of the ease of diffusion with hydrogen gas in the making of jewellery and medical instruments. Palladium has medical application in the timely treatment of tuberculosis, but other options were sought due to deleterious drawbacks. Other medical applications of palladium are their activities as anticancer and antimicrobial agents [51-57]. Ahmad et al. synthesized $\mathrm{Pd}(\mathrm{II})$ complex, $\left[\mathrm{Pd}\left(\mathrm{PPh}_{3}\right)_{2}(\operatorname{Imt})_{2} \mathrm{Cl}_{2} \cdot 3.5 \mathrm{H}_{2} \mathrm{O}\right]$, where Imt is imidazolidine-2thione, and screened it against two Gram-negative bacteria (Escherichia coli and Pseudomonas aeruginosa) and two yeasts (Candida albicans and Saccharomyces cerevisiae) [55]. They concluded that moderate activities were obtained from the antibacterial test, while significant activity was obtained from the yeast test.

Bakalova et al. synthesized four Pt(II), Pt(IV), Pd(II), and $\mathrm{Pd}(\mathrm{IV})$ coordination compounds using 3-amino- 


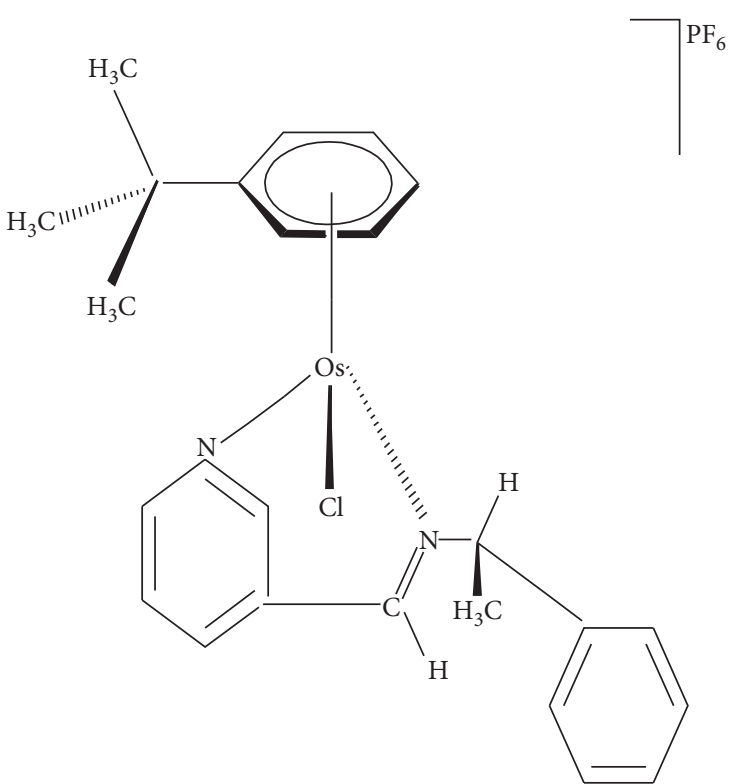

(a)

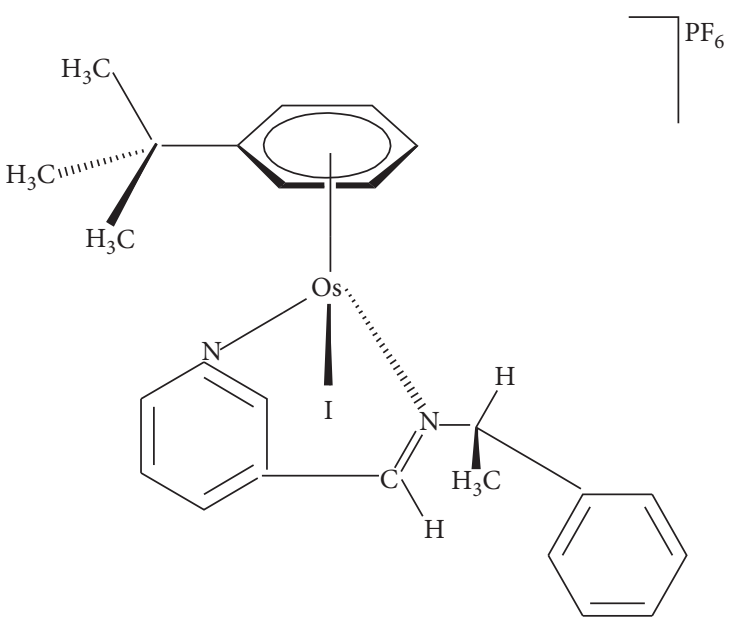

(c)

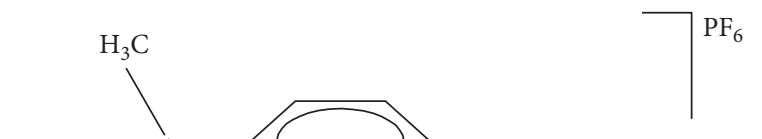<smiles>Cc1cccc(C(C)C)c1</smiles>

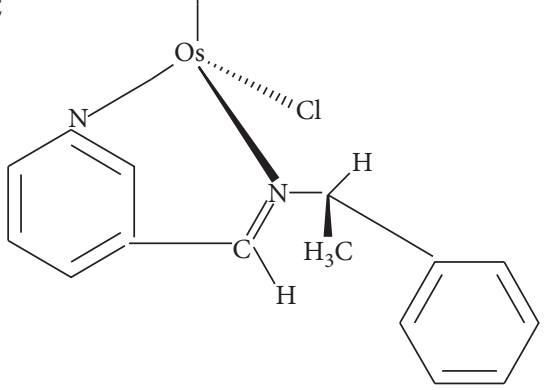

(b)

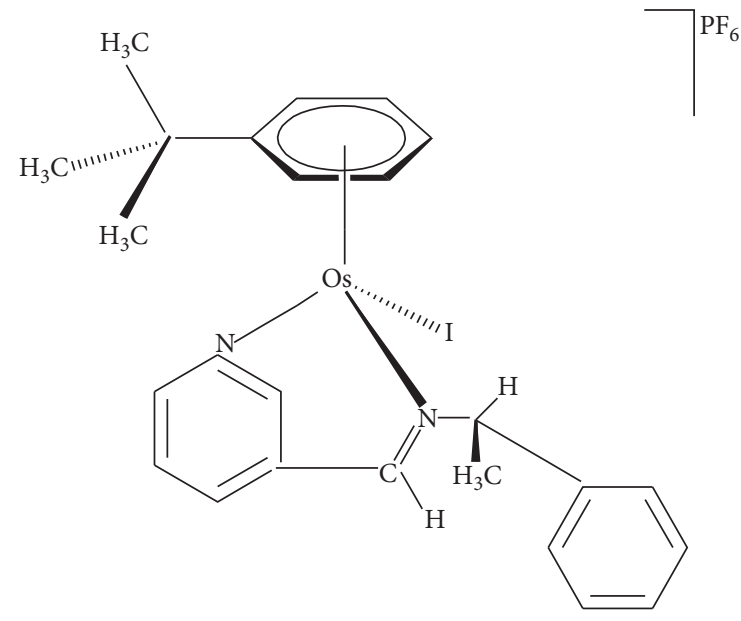

(d)

FIgURE 5: Chloro and iodido Os(II) arene anticancer complex.

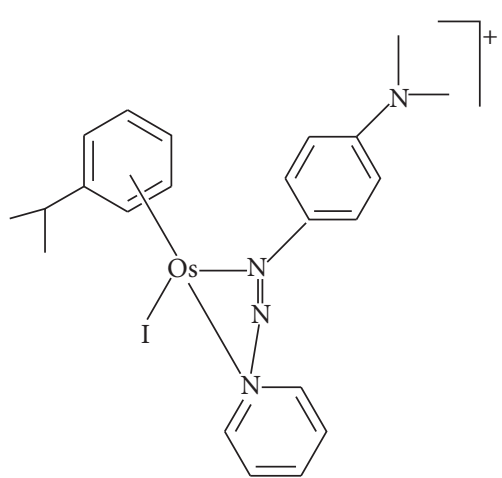

Figure 6: Osmium(II) arene anticancer complex with phenylazopyridine ligands.

$\alpha$-tetralonespiro- $5^{\prime}$-hydantoin as carrier ligand (Figure 9). All compounds were screened in vitro against SKW-3 human tumour cell line. $\mathrm{Pt}(\mathrm{II})$ coordination compound

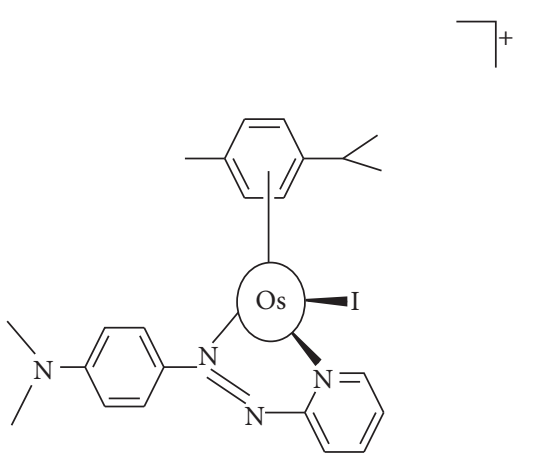

Figure 7: Osmium(II) azopyridine complex FY26.

exhibited higher antitumour activity than $\mathrm{Pd}(\mathrm{II})$ coordination compounds but lower activity than cisplatin [56]. Although different ligands were used and on a different mode of application, Ajibade and Idemudia reported the antibacterial efficacy of palladium complex with diaminopyrimidine of 


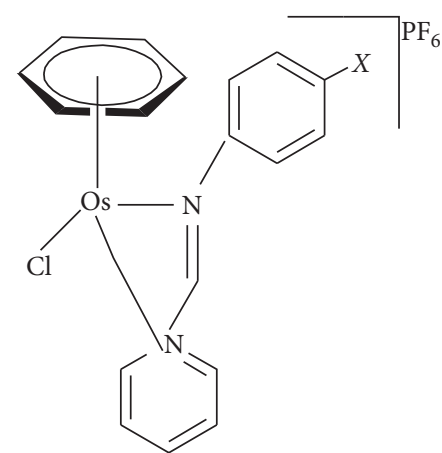

Figure 8: Molecular structure of $\left[\left(\mathrm{\eta}^{6}\right.\right.$-benzene $) \mathrm{OsCl}\left(\mathrm{C}_{5} \mathrm{H}_{4} \mathrm{~N}-2\right.$ $\left.\left.\mathrm{CH}=\mathrm{N}-\mathrm{C}_{6} \mathrm{H}_{5} X\right)\right]$ (where $X=\mathrm{p}-\mathrm{F}(1), p-\mathrm{Cl}(2), p-\mathrm{CH}_{3}\left(\mathrm{PF}_{6}\right)$ ).

nitrogen coordination mode (Figure 10) to be more potent than the platinum counterpart [58]. Contrary to Bakalova et al., $\mathrm{Pt}(\mathrm{II})$ showed higher efficiency as an antitumour agent than $\mathrm{Pd}(\mathrm{II})$ complex. Similar to Ajibade and Idemudiia, Wabamare et al. stated that the higher potency in-vitro antibacterial and antifungal activities of Pd(II) chiral Schiff base ligand complexes when compared with $\mathrm{Ni}(\mathrm{II})$ analogues against two Gram negative and Gram positive bacteria (Escherichia coli and Staphylococcus aureus), two fungi (Aspergillus niger (mold) and Candida albicans (yeast)) and ear pathogens [59]. They used mixed donor ligands containing nitrogen and oxygen atoms. Fong et al. were able to show from their proteomics data that stable cyclometalated platinum(II) N-heterocyclic carbene (NNC) complexes have both in vitro and in vivo anticancer activities [60]. According to Zhang and Sadler, the presence of biological thiols enables palladium(II) complexes to be stable. Their in vivo antibacterial studies showed their efficiencies to prevent tumour growth in an exposed rat model [47]. Their two palladium(II) complexes are shown in Figure 11. The challenge of using palladium complexes as anticancer and antimicrobial agents is the labile nature they possess compared with platinum complexes [47]. Elhusseiny and Hassan reported the dual activities of synthesized square planar $\mathrm{Pd}(\mathrm{II})$ complexes as antimicrobial and anticancer agents [51]. They used the nanoprecipitation method to prepare new thermally stable sphere-shaped aramides nanoparticles comprising flexible linkage ligands. The aramide nanoparticles were used to ligate $\mathrm{Pd}(\mathrm{II})$ ions to form $\mathrm{Pd}(\mathrm{II})$ complexes. The Pd(II) complexes were screened against Staphylococcus aureus (Gram-negative bacteria), Escherichia coli (Gram-positive bacteria), Aspergillus flavus (filamentous fungi), and Candida albicans (yeast), using the improved Kirby-Bauer disc diffusion method. Their polyamides having sulfones showed high efficiency as antibacterial and antifungal agents. All tested compounds are promising antimicrobial agents because they have lower zones of inhibitions than the standard drugs, namely, tetracycline and amphotericin, respectively, but higher zones of inhibitions than their corresponding ligands [51]. In the case of anticancer studies, the complexes were screened against three cell lines (breast carcinoma (MCF-7), colon carcinoma (HCT 116), and liver carcinoma (HEPG2)). Elhusseiny et al. reported that among the twelve synthesized Pd(II) complexes, three of
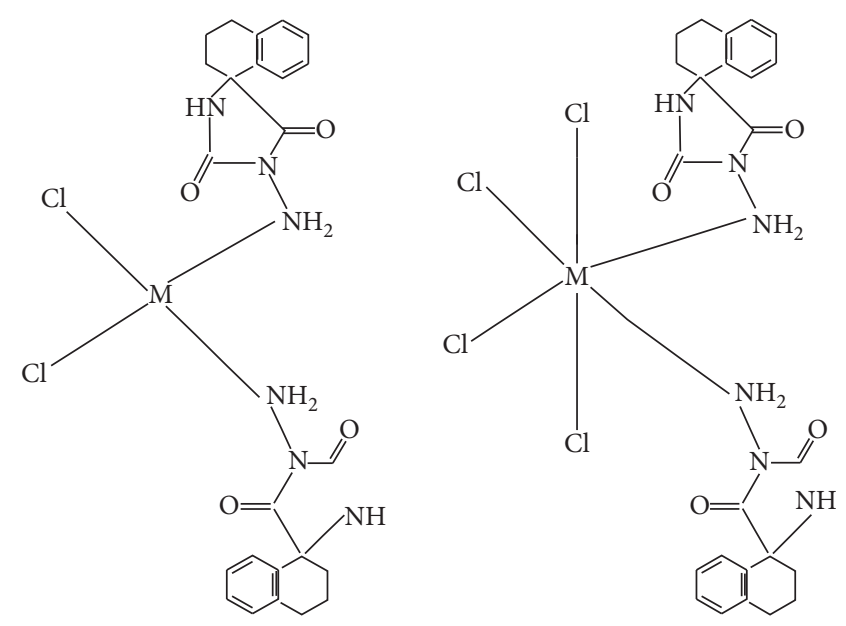

Figure 9: Four Pt(II), Pt(IV), Pd(II), and Pd(IV) coordination compounds using 3 -amino- $\alpha$-tetralonespiro- 5 '-hydantoin as carrier ligand (where $M=\mathrm{Pd}$ or $\mathrm{Pt}$ ).

them at $10 \mathrm{mg} / \mathrm{ml}$ concentration showed highest efficiencies against three cancer cell lines (HCT116, HEPG2, and MCF-7). These three Pd(II) complexes also showed highest efficiencies as antibacterial and antifungal agents [51]. They concluded that the presence of chloro groups in $\mathrm{Pd}(\mathrm{II})$ complexes resulted in their highest biological actions. In addition to the chloro groups, majority of the donor ligands used contained nitrogen and nitrogen to enhance biological activities as evident in the figures.

2.4. Platinum. In 1748, Antonio de Ulloa, a Spanish scientist, was given the recognition for discovery of platinum [61-64]. Platinum is a transition metal with a symbol of $\mathrm{Pt}$, atomic number of 78, and atomic mass of 195.084. Platinum has the origin from Spanish word, "platina," which means little silver. The commercial production is from the residue from the refinery of copper and nickel like other PGMs. Platinum is a silvery-white precious metal, which is malleable, ductile, does not easily oxidize in air, and occurs freely in nature and in combined state with iridium. The leading manufacturer of refined platinum is the Merensky Reef in the Bushveld Igneous Complex (BIC) in South Africa. It manufactures $80 \%$ of the world's production, and the alluvial deposit is found in Ural Mountains in Russia and in western American states. Platinum has numerous applications. The industrial and chemical applications are making jewellery and coinage, cigarette lighters, crucibles, catalysts, catalytic converters for automobiles, hand warmers, oxygen sensors, pipelines, strong magnets, spark drugs, and turbine engines. Pre-Columbian Americans used it to make artefacts. In the years between 1889 and 1960, 90\% of platinum alloy was used as the international standard to define one meter. There has been progress of platinum drugs from cisplatin to third-generation drugs [65]. In medicine, platinum is used to build dental crowns and dentistry instrument and used as antitumour agents. Platinum is applied both as anticancer and antimicrobial agents [65]. From Barnett Rosenberg et al.'s article in "Nature," they carried out 
<smiles></smiles>

(a)

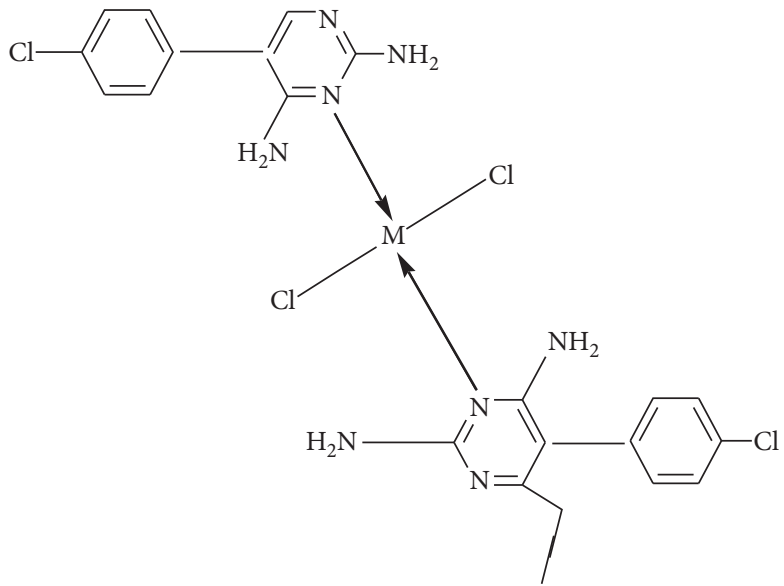

(c)<smiles>COc1cc(Cc2c(N)ncn2C([Al])([As])n2cc(N)c(Cc3cc(OC)c(OC)c(OC)c3)c2)cc(C)c1OC</smiles>

(b)

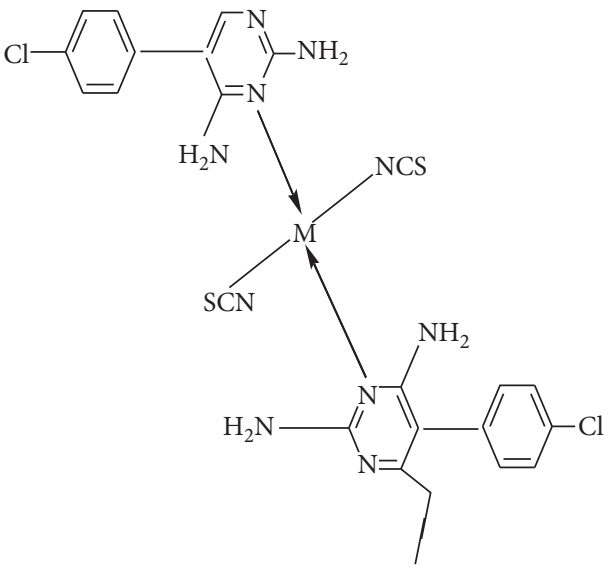

(d)

FIgURE 10: Palladium complex with diaminopyrimidine ligands (where $M=$ palladium or platinum).<smiles>[R]N1C=CN([R])C1[R1](Cl)(Cl)C1N([R])C=CN1[R]</smiles>

(a)

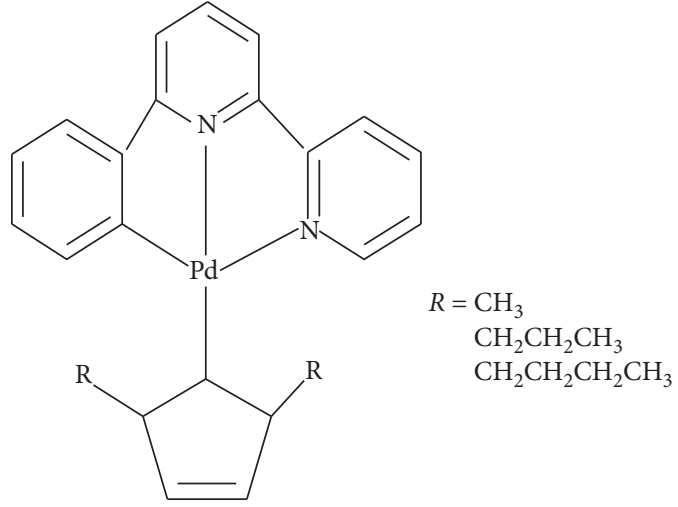

(b)

Figure 11: Palladium(II) NHC complexes.

a research on the potential impacts of electromagnetic field on development in bacteria [66]. The research involved platinum electrodes, ammonium chloride as electrolyte, and concentrations in parts per million of specific group of VIIIb of the d-block metallic compounds in the culture media [66-71]. They observed that there was a chemical reaction between ammonium chloride and the inert platinum electrodes, which led to the formation of trans-dichlorodiamineplatinum. This 
was inactive on the bacteria, but when exposed to light, it was converted to cis-dichlorodiamineplatinum, known as cisplatin, which had inhibition on the bacterial cell division [66-68]. A study of the literature on cisplatin revealed that it was synthesized in 1848, resynthesized in 1890, and referred to as Peyrone's chloride, which led to the discovery of the isomerism and initiation of coordination chemistry [66-68]. Platinum was found to possess antibacterial properties [65-67]. Biophysicist, Barnett Rosenberg, incidentally discovered cisplatin as having potentials and potencies as efficient anticancer agents [66-68]. In 1964, the first metallocomplex anticancer drug named cisplatin $\left[\mathrm{Pt} \mathrm{Cl}_{2}\right.$. $\left.\left(\mathrm{NH}_{3}\right)\right]$ was discovered. It started the development of metal-based anticancer drugs. Between 1977 and 1978, the United States Food and Drug Administration (FDA) endorsed cisplatin. The therapeutic application of cisplatin in the study of cancer had led to treatment of various types of cancer, such as bladder, ovaries, and head and neck malignancies [66-68]. The side effects of emetogenesis, nephrotoxicity, neurotoxicity, and ototoxicity that cancer patients experienced led to synthesis of carboplatin which had less toxicity compared with cisplatin [68]. Lack of selectivity of cisplatin led to other analogues of cisplatin with potentials for anticancer activities. Some examples are carboplatin, nedaplatin, ZD0437, AMD473, and oxaliplatin. Some chemical structures of some platinum anticancer drugs are shown in Figure 12 [67]. Ndagi et al., Kostova et al., and Manav et al., reported the impact of metal complexes in terms of improving compounds design to reduce toxicity, control drug resistance, and appreciate the action mechanisms in medicine $[69,72,73]$. Kostova et. al showed eight platinum(II) and platinum(IV) molecular structures having nitrogen-nitrogen donors and nitrogenoxygen donors. They stated that there was no significant change in the effectiveness of $\mathrm{Pt}(\mathrm{II})$ or $\mathrm{Pt}(\mathrm{IV})$ coordination compounds to produce cytotoxicity in multicellular tumour spheroids (MCTS) compared to monolayer cultures. They suggested combination therapy as a promising approach to fight against cancer because combining drugs with diverse modes of action often synergises their impacts. Ajibade and Idemudia reported the antibacterial activities of platinum(II) complex with diaminopyrimidine ligand (nitrogen and nitrogen coordination modes) [58]. Their minimum inhibition concentration (MIC) and minimum bacterial concentration (MBC) confirmed that $\mathrm{Pt}(\mathrm{II})$ complexes were less active than their group member Pd(II) complexes. Similarly, on antibacterial activities, Manav et al. reported and studied Pt(IV) dithiocarbamato complexes (sulphur and sulphur coordination modes). From their in vitro bacterial study, they discovered that the complexes when tested against E. coli, B. subtilis, $P$. aeruginosa $K(P A K), P$. aeruginosa, and $Z$. mobilis bacterial strains showed less activities (Table 1).

Additionally, one of the complexes tested for its in vitro antitumour activities against adenocarcinoma (human colour) cell line at various concentrations between $10 \mu \mathrm{M}$ and $10 \mathrm{pM}$ showed good activity at 100 and $10 \mu \mathrm{M}$ solutions, but further dilutions gave proliferation. The in vivo testing on various organs, such as the bladder, brain, kidney, and liver, of rabbits exhibited no adverse effect. Dimethy lsulfoxide (DMSO) was used as negative control, while 3-[4,5dimethylthiazol-2-yl]-2,5-diphenyltetrazolium bromide (MTT) was used as positive control. On a different note, Andrew and Ajibade stated the cytotoxic activities of platinum(II) complex with 1-phenylpiperazine dithiocarbamato ligand (sulphur and sulphur coordination modes) to be less active when compared to the standard drug, parthenolide [74]. The cancer cell lines used for the study were TK10 (renal), UACC62 (melanoma), and MCF-7 (breast). The cell growth inhibition $\left(\mathrm{IC}_{50}\right)$ accordingly was $>100,>100$, and 66.82 , as against the $\mathrm{IC}_{50}$ of parthenolide given as $4.64,11.37$, and 3.52, respectively (Table 2).

Drug design influences the development of improved platinum and palladium-based polyamine anticancer agents with a focus on controlled delivery to promote less toxic cytotoxic activity $[69,75-80]$.

Fast development of nanobiotechnology enables the possibility of targeted delivery of antibacterial and anticancer platinum agents to deliver platinum drugs to bacterial and cancer sites [77]. In this manner, it reduces toxicity and increases drug efficiency. This progress in the use of nanodelivery strategies is increasing, whereby platinum warheads were incorporated into nanomedicine concepts. Nanoparticles designed to deliver platinum(IV) complexes include carbon nanotubes, carbon nanoparticles, gold nanoparticles, quantum dots, polymeric micelles, upconversion nanoparticles, and nanoformulations (coordination polymers, metal-organic frameworks, peptides, proteins, and supramolecular self-assembled structures) [76-79]. Inorganic nanoparticles-based drug carriers with exceptional theranostic effects are relevant and better than polymeric and lipid nanoparticles [77].

2.5. Rhodium. Rhodium with the symbol $\mathrm{Rh}$ is a transition metal, PGM, and has atomic number of 45 and atomic mass of 102.9055. William Hyde Wollaston, an English chemist, who discovered palladium, also discovered rhodium when investigating platinum ores from Peru in London in 1803 $[50,81]$. Hippolyte-Victor Collet-Descotilis drew Wollaston's attention to the option of a novel element, which had a red colour [50]. The origin of rhodium came from Greek word, "rhodon," meaning rose. The commercial production of rhodium is got from byproduct of refinery of ores of nickel-cobalt sulfides. It is a hard, silvery-white lustrous metal with a low density. It is has high reflectance and is very resistant to corrosion. It is nonreactive to most acids and does not form oxides. The industrial and chemical applications include their use as alloys to strengthen resistance to corrosion of palladium and platinum, as electrical contact substance due to its low electrical resistance, and for making jewelleries and decorations. The medical applications involve acting as anticancer and antimicrobial agents in the Rh(I), Rh(II), and $\mathrm{Rh}(\mathrm{III})$ states $[25,82-94]$. Jeremić et al. stated that $\mathrm{Rh}^{\mathrm{III}}$ complexes are isoelectronic with $\mathrm{Rh}^{\mathrm{II}}$ and $\mathrm{Pt}^{\mathrm{IV}}$ 
<smiles>N[PH](N)(Cl)Cl</smiles>

(a)<smiles>N[P+]1(N)OCC(=O)O1</smiles>

(c)<smiles>Cc1ccccc1[Pb](N)(Cl)Cl</smiles>

(e)

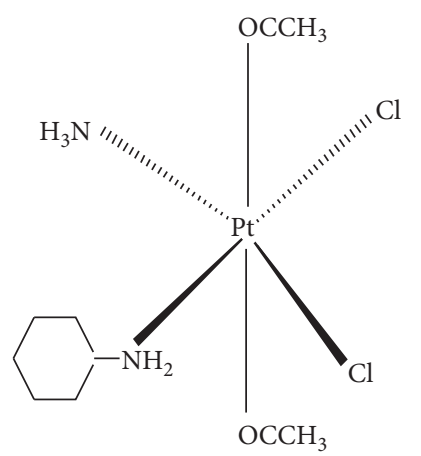

(g)<smiles>N[PH]1(N)OC(=O)C2(CCC2)C(=O)O1</smiles>

(b)<smiles>CC1C=CC=CN1[P](N)(Cl)Cl</smiles>

(d)<smiles>C[C@@H]1CCCC[C@H]1N</smiles>

(f)

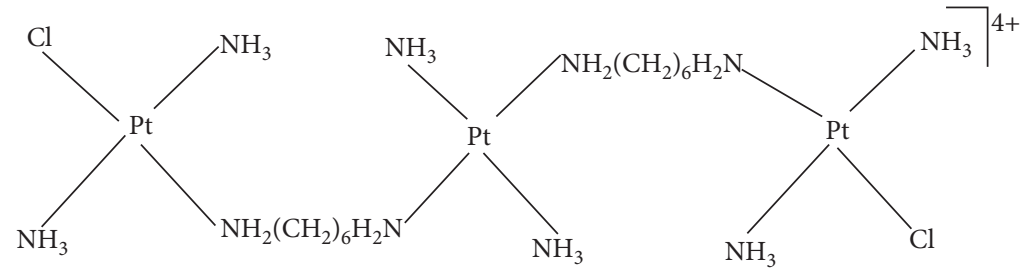

(h)

Figure 12: Pt(II) and Pt(IV) anticancer drugs. (a) Cisplatin. (b) Carboplatin. (c) Nedaplatin. (d) ZD0437. (e) AMD473. (f) Oxaliplatin. (g) JM216. (h) BBR3464.

TABLE 1: Antibacterial activities of platinum(IV) dithiocarbamato complexes in $\mu \mathrm{M}$.

\begin{tabular}{lccccc}
\hline $\mathrm{Pt}(\mathrm{IV})$ complex & Z. mobilis & B. subtilis & K. aeroginosa & E. coli & P. aeruginosa \\
\hline$\left[\mathrm{Pt}\left(\mathrm{L}^{1}\right)_{2} \mathrm{Cl}_{2}\right]$ & + & ++ & - & - & + \\
{$\left[\mathrm{Pt}\left(\mathrm{L}^{3}\right)_{2} \mathrm{Cl}_{2}\right]$} & ++ & - & - & - & + \\
{$\left[\mathrm{Pt}\left(\mathrm{L}^{4}\right)_{2} \mathrm{Cl}_{2}\right]$} & - & ++ & - & + & + \\
\hline
\end{tabular}

$\mathrm{L}^{1}=$ morpholine dithiocarbamate, $\mathrm{L}^{3}=N$-(methyl, cyclohexyl dithiocarbamate, and $\mathrm{L}^{4}=N$-(ethyl, cyclohexyl dithiocarbamate).

Table 2: Comparison of studied Pt(II) complex and parthenolide against three cancer cell lines in $\mu \mathrm{M}$.

\begin{tabular}{lccc}
\hline & \multicolumn{3}{c}{ Three cancer cell lines } \\
\hline Studied compounds & TK10 & UACC62 & MCF-7 \\
Pt(II) complexes & $>100$ & $>100$ & 66.82 \\
Parthenolide & 4.64 & 11.37 & 3.52 \\
\hline
\end{tabular}

coordination compounds, which offer a variety of effective antitumour agents [83]. They further noted their geometry as octahedral and their biological activities as being antimicrobial and antitumour. Additionally, Geldmacher et al. reported that rhodium compounds have significant antitumour activities but are less active than anticancer agents because of their toxic effects. Monomeric square 
planar $\mathrm{Rh}(\mathrm{I}), \mathrm{Rh}(\mathrm{II})$ dimeric $\mu$-acetato dimers, and octahedral $\mathrm{Rh}$ (III) coordination compounds have shown remarkable antitumour properties [94]. Some rhodium compounds are in phase I anticancer clinical trials [95]. Rhodium has a disadvantage of nephrotoxicity when applied as anticancer agent [95]. In order to improve the antibacterial and anticancer properties of rhodium, it could act as half-sandwich with PGMs [96]. Markham et al. reported six $\mathrm{Rh}(\mathrm{III})$ complexes with $\mathrm{Rh}(\mathrm{III})$ complexes (Figure 13) with the general formula, $\left[\mathrm{Rh}^{\mathrm{III}}\left({ }^{*} \mathrm{Cp}\right.\right.$ ) $\mathrm{Cl}(X, y)]^{\mathrm{n}+}$ coordination compounds $\{X, Y=\mathrm{Cl}$, PTA, $n=0(2)$; $X, Y=$ en, $n=1$ (3, $\mathrm{Cl}^{-}$salt; $4, \mathrm{PF}_{6^{-}}$salt) $X, y=\mathrm{acac}, n=0$ (5); $X$, $Y=$ cur, $n=0$ (6), where ${ }^{*} \mathrm{Cp}=$ pentamethylcyclopentadienato, curH $=$ curcumin; PTA = 1, 3, 5-triaza-7-phosphatricyclo[3.3. 1.1 $]$ decane; $\quad$ en =1,2-ethanediamine,$\quad$ acac $=$ acetylacetonate $=2,4$-pentanedionato $(1-)\}$ were prepared from $\left[\mathrm{Rh}\left({ }^{*} \mathrm{Cp}\right)\right.$ $(\mu \text {-Cl) } \mathrm{Cl}]_{2}(1)$. Among the six $\mathrm{Rh}(\mathrm{III})$ complexes, only complex 6 showed cytotoxic action against human epithelial A549 lung cancer cell line [97]. Jeremić et al. in line with Markham et al. synthesized two $\mathrm{Rh}(\mathrm{III})$ complexes ([Rh(ed3a) $\left.\left(\mathrm{OH}_{2}\right)\right] \cdot \mathrm{H}_{2} \mathrm{O}$, $(2)=\mathrm{Na}\left[\mathrm{Rh}(\right.$ ed3a) $\left.(\mathrm{Cl})] \cdot \mathrm{H}_{2} \mathrm{O}\right)$ and discovered the complex with hydroxyl group (1) gave higher cytotoxic activity against MRC-5, MCF-7, A549, HT-29, and HeLa cancer cell lines (Table 3). As stated earlier, Adhikari et al. studied half-sandwich rhodium(II)) complex comprising 2-substituted 1,8-napthyridine ligands with unexpected bonding modes, but the result was less active than that of cisplatin (Figure 1). The nanoparticles could also act as nanovehicles for anticancer drugs [97].

2.6. Ruthenium. Ruthenium with the symbol Ru is a d-block transition metal, PGM, and has an atomic number of 44 and a mass number of 101.0 [98]. In 1808, Jedrzej Sniadecki, a Polish chemist, discovered ruthenium in South America and named it "vestium" after the asteroid Vesta [98]. In 1928, Gottfried W. Osann, a Russian chemist, rediscovered ruthenium due to inability to confirm Jedrzej Sniadecki's discovery [99]. In 1944, Karl Karlovich Klaus (Carl Ernst Claus), another Russian chemist, did a second discovery of ruthenium, also due to inability to prove Gottfried W. Osann's discovery which was able to be verified $[99,100]$. This made authorities to refer to him as the discoverer. The origin of the name has a derivation from, "Ruthenia," meaning Russia [100]. The sources of ruthenium are indigenous in mineral ores in Ural Mountains, North America, and South America. It can also be found in pyroxinite in South Africa. Ruthenium is a hard white metal and also a transition metal that is rare. Ruthenium is the only element with two electrons in the outermost shell in Group 8. It has no less than eight oxidation states; the commonest are $+2,+3$, and +4 . Ruthenium tetroxide is very toxic and has the tendency to be explosive. Ruthenium has chemical and industrial applications, which include corrosion resistance when mixed with titanium, as platinum alloys, as catalysts, and as superconductor when alloyed with molybdenum at a temperature below $10 \mathrm{~K}$. Ruthenium, rhodium, and iridium complexes are the most active and chosen hydrogen transfer catalysts. Among the three complexes of iridium, rhodium, and ruthenium, ruthenium complexes are superior due to their low cost and high activity [101]. Of all ruthenium compounds, arene ruthenium compounds have robust metal-organic molecules which are essential for organometallic chemistry development [101]. Three major characteristics make ruthenium compounds suitable for medical applications such as ability to imitate iron to bind to certain biological molecules, slow rate of ligand exchange, and the variable oxidation states $[102,103]$. They can be applied as anticancer and antimicrobial agents for oxidation states of +2 , +3 , and +4 [24, 103-121]. In history, ruthenium complexes examined were chloro-ammine-Ru(III) compounds. In 1980, Allardyce et al. gave an account of the anticancer potentials of fac chloro-ammine-Ru(III) compounds in models of murine, but there was discontinuation due to solubility problems [103]. In 1984, researchers worked on the anticancer properties of ruthenium(II) complex, cis$\left[\mathrm{RuCl}_{2}(\mathrm{DMSO})_{4}\right]$, and found that it was noncytotoxic in both in vitro and in vivo activities, except at maximum dose [122]. In 1988, trans- $\left[\mathrm{RuCl}_{2}(\mathrm{DMSO})_{4}\right]$ proved more potent, though more toxic than the cis isomer against Lewis lung carcinoma and primary tumour metastases. Scolaro et al. proved that nonplatinum potent complexes such as isostructural $\mathrm{Ru}$ (III) complexes, [ImH] trans$\left[\mathrm{RuCl}_{4}(\mathrm{Im})_{2}\right.$ and $[\mathrm{IndH}]$ trans- $\left.\left[\mathrm{RuCl}_{4}(\mathrm{Ind})_{2}\right)\right](\mathrm{ICR}, \mathrm{KP}$ 1019), were more active than platinum against colorectal autochthonous tumours $[123,124]$. In early 90s, [Na] trans-[ $\mathrm{RuCl}_{4}$ (Im) (DMSO-S)] (NAMI), which is similar to KP 1019, was prepared, having an S-bonded DMSO to substitute an imidazole [104]. Later on, at the preclinical stage, imidazolium salt $[\mathrm{ImH}]$ trans- $\mathrm{RuCl}_{4}$ (Im) (DMSOS) substituted NAMI and was named NAMI-A [105]. NAMI-A has the potentials to efficiently inhibit development and growth of pulmonary metastases in all in vivo activities of solid tumours. Historically, the three classes of anticancer ruthenium compounds, Ru-DMSO, Ru(III) complexes of $[\mathrm{LH}]$ trans- $\left[\mathrm{RuCl}_{4}(\mathrm{~L})_{2}\right]$, and organometallic $\mathrm{Ru}(\mathrm{II})$ arene $\left[\left(\eta^{6}\right.\right.$-arene $\left.) \mathrm{Ru}(\mathrm{en}) \mathrm{Cl}\right]\left[\mathrm{PF}_{6}\right]$, have general biological and chemical properties. Among the organometallic $\mathrm{Ru}(\mathrm{II})$ arene $\left[\left(\eta^{6}\right.\right.$-arene) $\mathrm{Ru}$ (en) $\left.\mathrm{Cl}\right]\left[\mathrm{PF}_{6}\right]$ compounds are $\left[\mathrm{Ru}\left(\eta^{6}\right.\right.$-arene $\left.) \mathrm{Cl}_{2}(\mathrm{PTA})\right]$ (RAPTA) derivatives (RAPTA-C, oxalo-RAPTA-C, carbo-RAPTA-C and RAPTA-T) [125-127]. The three classes were verified to be active in vivo [118]. NAMI-A and KP 1019 are currently in phase II clinical trials. A main challenge in the use of ruthenium complexes as therapeutic agents is restricted stability in aqueous solutions, which had led to reassessment of their medical applications [112]. Some sandwich and half-sandwich ruthenium(II) complexes with anticancer activities are shown in Figures 14(a)-14(d). Recently, Heterobimetallic coordination half-sandwich compounds of Ir (III) and $\mathrm{Ru}(\mathrm{II})$ yield improved anticancer activities due to the possession of chelating ligands and reduction-oxidation features [128-132], while Téllez et al. obtained better results with a half-sandwich mixture of iridium, rhodium, and ruthenium coordination compounds [132].

Zeng et al. reported the challenge faced with ruthenium nanoparticles, whereby their particle size and specificity of target of organs are hindrances to efficient antitumour 


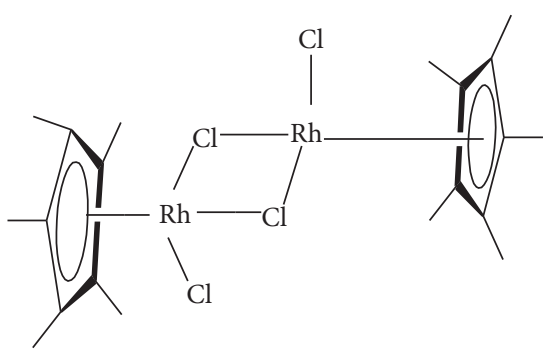

(a)

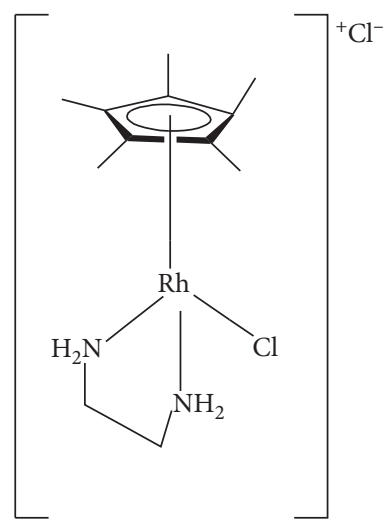

(c)

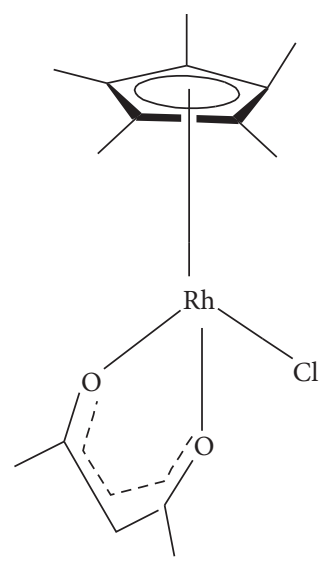

(e)

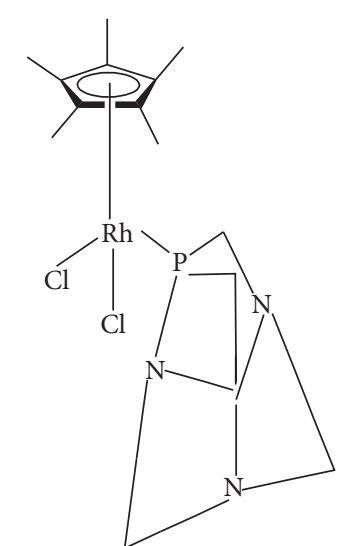

(b)

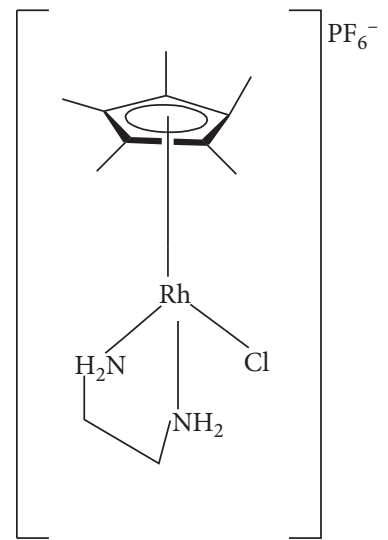

(d)<smiles>Cc1c(C)c(Br)c(C)c(COC(=O)/C=C/c2ccc(O)c([O-])c2)c1C</smiles>

(f)

Figure 13: Molecular structures of (pentamethylcyclopentadienato) $\mathrm{Rh}(\mathrm{III})$ complexes. (a) $\left[\mathrm{Rh}\left({ }^{*} \mathrm{Cp}\right) \mathrm{Cl}\left(\mu^{2}-\mathrm{Cl}\right)\right]_{2}$. (b) $\left[\mathrm{Rh}\left({ }^{*} \mathrm{Cp}\right) \mathrm{Cl}{ }_{2}(\mathrm{PTA})\right]$. (c) $\left[\mathrm{Rh}\left({ }^{*} \mathrm{Cp}\right) \mathrm{Cl}(\right.$ en $\left.)\right] \mathrm{Cl}$. (d) $\left[\mathrm{Rh}\left({ }^{*} \mathrm{Cp}\right) \mathrm{Cl}(\right.$ en $\left.)\right] \mathrm{PF}_{6}$. (e) $\left[\mathrm{Rh}\left({ }^{*} \mathrm{Cp}\right) \mathrm{Cl}(\mathrm{acac})\right] .(\mathrm{f})\left[\mathrm{Rh}\left({ }^{*} \mathrm{Cp}\right) \mathrm{Cl}(\mathrm{cur})\right]$.

TABle 3: Cytostatic activities of $\mathrm{Rh}(\mathrm{III})$ coordination compounds and ed3a3 ligand against tumour strains in $\mu \mathrm{M}$.

\begin{tabular}{lccccc}
\hline Compound $\mathrm{IC}_{50}(\mathrm{mM})$ & MRC-5 & MCF-7 & A549 & HT-29 & HeLa \\
\hline$(1)$ & $>100$ & $>100$ & 16.83 & 1.96 & 1.10 \\
$(2)$ & $>100$ & $>100$ & 24.28 & 37.64 & 20.54 \\
$\mathrm{Na}_{2} \mathrm{Hed} 3 \mathrm{a}$ & $>100$ & $>100$ & 18.01 & $>100$ & 13.86 \\
Doxorubicin & 0.12 & 0.75 & 7.86 & 0.32 & 1.17 \\
Cisplatin & 0.45 & 1.5 & 36.12 & 22.05 & 2.02 \\
\hline
\end{tabular}

$(1)=\left[\mathrm{Rh}(\right.$ ed3a $\left.)\left(\mathrm{OH}_{2}\right)\right] \cdot \mathrm{H}_{2} \mathrm{O} ;(2)=\left[\mathrm{Rh}\left(\right.\right.$ ed3a) $\left.\left(\mathrm{OH}_{2}\right)\right] \cdot \mathrm{H}_{2} \mathrm{O}$. activities [133]. They suggested the solution of drug encapsulation (developed nanomaterials) in order to provide biodistribution, pharmacokinetics, solubility, and toxicity. In addition, they stated that previous studies revealed enraptured $\mathrm{Ru}(\mathrm{II})$ coordination compounds in nanomaterial system improved their target and delivering into tumour cells. The four roles played by $\mathrm{Ru}(\mathrm{II})$ complexes in nanomaterial systems are to curtail drug release with better effectiveness, to work as catalysts or drugs in the nanomaterial systems, to increase the 
<smiles></smiles>

(a)

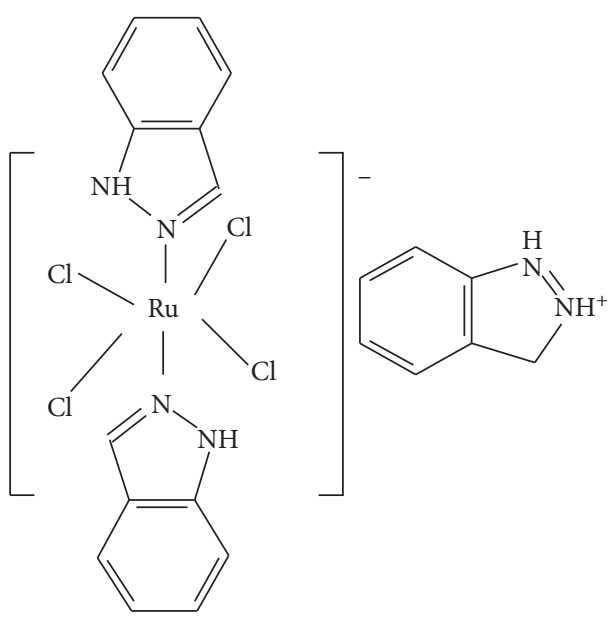

(b)
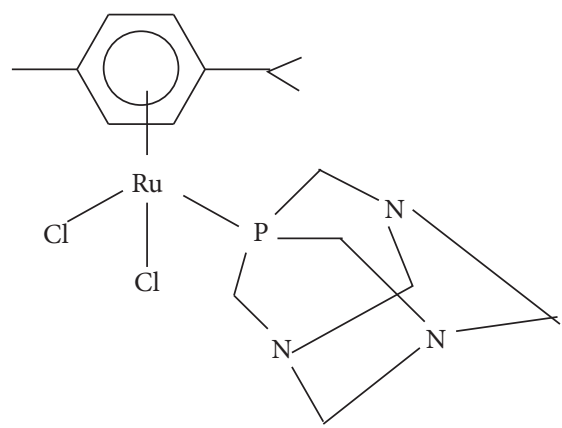

(c)

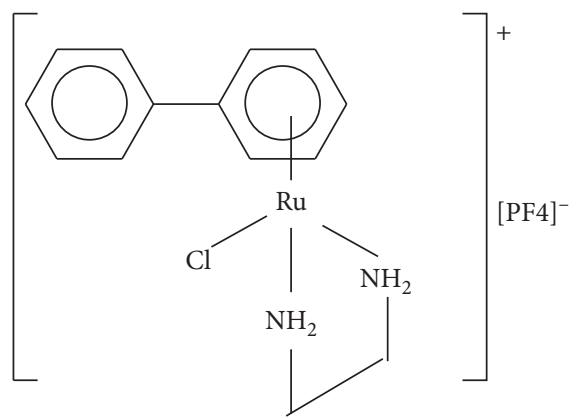

(d)

Figure 14: (a, b) Examples of ruthenium complexes and organometallic arene piano-stool ruthenium agents of Dyson; antimetastatic (c) RAPTA and (d) RAPTA-C complex. (a) NAMI-A, (b) KP 1019, (c) RAPTA, and (d) RAPTA-C.

photochemical efficiency and nanomaterials stabilities, and to act as theranostic tools to trace imported nanomaterials via luminescence imaging [133].

\section{Conclusion and Future Direction}

Platinum-group metals are useful as a two-fold anticancer and antibacterial agent. The most relevant among organoiridium coordination compounds are the coordination compounds of iridium(III). In the case of osmium coordination compounds, there exist osmium(II) and osmium(VI) as anticancer and antimicrobial agents. For palladium and platinum coordination compounds, the most relevant as antibacterial and anticancer are $\mathrm{Pd}(\mathrm{II})$ and $\mathrm{Pt}(\mathrm{II})$ respectively. Rhodium coordination compounds have $\mathrm{Rh}(\mathrm{I}), \mathrm{Rh}(\mathrm{II})$, and $\mathrm{Rh}(\mathrm{III})$ anticancer and antimicrobial agents, while ruthenium has $\mathrm{Ru}(\mathrm{II})$ and $\mathrm{Ru}(\mathrm{III})$ anticancer and antimicrobial agents. Sandwich and half-sandwich PGMs enhance the antibacterial and anticancer activities of PGMs.

In summary, most researchers used nitrogen-nitrogen coordination modes to synthesize Ir(III) complexes, but Lucas et al. obtained potent results using nitrogenoxygen coordination modes. Iridium(III) complexsupported nanomaterials for luminescence sensing are applied in intracellular imaging. Most researchers who studied Os(III) complexes used nitrogen-nitrogen donor ligands, and chloro and iodidosubstituents to enhance anticancer activities. They showed higher potencies when compared with cisplatin and their effectiveness as antibacterial agents. They are also reported to act as luminescent bioimaging. Chloro substituents also aided $\mathrm{Pd}(\mathrm{II})$ complexes in their biological applications. Labile challenges of palladium nanoparticles brought limitation to its biological applications; therefore, the researcher mentioned for the review had to apply the nanoprecipitation method for the ligands' syntheses, while others used green chemistry, outside this review. Platinum nanoparticles-based drug carriers with exceptional theranostic effects. Chloro substituents improve $\mathrm{Pd}(\mathrm{II})$ complexes for their biological applications. Chloro and hydroxyl substituents also improve rhodium complexes for their biological applications. Rhodium nanoparticles could act as nanovehicles for anticancer drugs. Chloro and ammine substituents aided ruthenium complexes in their biological applications. Drug encapsulation was suggested to control the particle charge challenge of ruthenium nanoparticles.

Future direction will involve the assessment of the dinuclear complexes of PGMs as antibacterial and anticancer agents with chloro and hydroxyl substituents, as well as their nanocarrier and bioimaging activities. 


\section{Conflicts of Interest}

The authors declare no conflicts of interest.

\section{Acknowledgments}

The authors appreciate Govan Mbeki Research and Development Centre (GMRDC) for financial assistance.

\section{References}

[1] R. J. McQuitty, “Metal-based drugs," Science Progress, vol. 97, no. 1, pp. 1-19, 2014.

[2] Y. Ellahioui, S. Prashar, and S. Gómez-Ruiz, "Anticancer applications and recent investigations of metallodrugs based on gallium, tin and titanium," Inorganics, vol. 5, no. 1, p. 4, 2017.

[3] M. P. M. Marques, "Platinum and palladium polyamine complexes as anticancer agents: the structural factor," ISRN Spectroscopy, vol. 2013, Article ID 287353, 29 pages, 2013.

[4] A. Rajini, M. Nookaraju, V. Venkatathril, and A. K. Reedy, "Synthesis, characterization, antimicrobial and cytotoxic studies of a novel vanadium dodecylamino phosphate," Arabian Journal of Chemistry, vol. 10, pp. S2082-S2089, 2017.

[5] N. R. Palepu, R. Premkumar, A. K. Vemar et al., "Antibacterial, in vitro antitumour activity and structural studies of rhodium and iridium complexes featuring the two positional isomers of pyridine carbaldehyde picolinic hydrazone ligand," Arabian Journal of Chemistry, vol. 11, no. 5, pp. 714-728, 2018.

[6] S. Senepati, A. K. Mahanta, S. Kumar, and P. Maiti, "Controlled drug delivery vehicles for cancer treatment and their performance," Signal Transduction and Targeted Therapy, vol. 3, no. 1, 2018.

[7] C. Moorthi, L. R. Manavalan, and K. Kathiresan, "Nanotherapeutics to overcome conventional cancer chemotherapy limitations," Journal of Pharmacy \& Pharmaceutical Sciences, vol. 14, no. 1, pp. 67-77, 2011.

[8] J. Mondal, A. K. Panigrahi, and A. R. Khuda-Bukhsh, "Conventional chemotherapy: problems and scope for combined therapies with certain herbal products and dietary supplements," Austin Journal of Molecular and Cellular Biology, vol. 1, pp. 1-10, 2014.

[9] K. T. Nguyen, "Targeted nanoparticles for cancer therapy: promises and challenges," Journal of Nanomedicine \& Nanotechnology, vol. 2, no. 5, pp. 1-2, 2011.

[10] D. G. Lewis, "The early life of Smithson tennant FRS (17611815) 250 th anniversary of the birth of the discoverer of iridium and osmium," Platinum Metals Review, vol. 55, no. 3, pp. 196-200, 2011.

[11] A. Markowska, B. Kasprzak, K. Jaszcyńska-Mowinka, J. Lubin, and J. Markowska, "Noble metals in oncology," Współczesna Onkologia, vol. 4, pp. 271-275, 2015.

[12] H. Rolf and P. Zaffalon, "Osmium vs. Ptène: the naming of the densest metal," Johnson Matthey Technology Review, vol. 61, no. 3, pp. 190-196, 2017.

[13] J. Wisniak, "Smithson tenant," Educación Química, vol. 26, no. 3, pp. 250-259, 2015.

[14] P. Pykkö and W. H. Xu, "On the extreme oxidation states of iridium," Chemistry-A European Journal, vol. 21, no. 26, pp. 9468-9473, 2015.
[15] Z. Liu and P. J. Sadler, "Organoiridium complexes: anticancer agents and catalysts," Accounts of Chemical Research, vol. 47, no. 4, pp. 1174-1185, 2014.

[16] F. Chen, J. Moat, D. McFeely et al., "Biguanide iridium(III) complexes with potent antimicrobial activity," Journal of Medicinal Chemistry, vol. 61, no. 16, pp. 7330-7344, 2018.

[17] L. Lu, L. Liu, W. Chao et al., "Identification of an iridium(III) complex with anti-bacterial an anti-cancer activity," Scientific Reports, vol. 5, no. 1, pp. 1-9, 2015.

[18] S. Dave and N. Bansal, "Application of schiff bases as therapeutic agent-a review," International Journal of Current Pharmaceutical Research, vol. 5, pp. 1-7, 2013.

[19] Z. Almodares, S. J. Lucas, B. D. Crossley et al., "Rhodium, iridium, and ruthenium half-sandwich picolinamide complexes as anticancer agents," Inorganic Chemistry, vol. 53, no. 2, pp. 727-736, 2014.

[20] S. J. Lucas, R. M. Lord, R. L. Wilson, R. M. Phillips, V. Sridharan, and P. C. McGowan, "Synthesis of iridium and ruthenium complexes with $(\mathrm{N}, \mathrm{N}),(\mathrm{N}, \mathrm{O})$ and $(\mathrm{O}, \mathrm{O})$ coordinating bidentate ligands as potential anti-cancer agents," Dalton Transactions, vol. 41, no. 45, pp. 13800-13802, 2012.

[21] R. G. Buckley, "Rhodium, iridium and palladium compounds as experimental anticancer drugs," in Metal Compounds in Cancer Therapy, S. P. Fricker, Ed., Springer, Netherlands, pp. 92-108, 1994.

[22] G. Gasser, I. Ott, and N. Metzler-Nolte, "Organometallic anticancer compounds," Journal of Medicinal Chemistry, vol. 54, no. 1, pp. 3-25, 2011.

[23] V. K. Sharma, A. Srivastava, and S. Srivastava, "Synthetic, structural and antifungal studies of coordination compounds of $\mathrm{Ru}(\mathrm{III}), \mathrm{Rh}(\mathrm{III})$ and $\mathrm{Ir}(\mathrm{III})$ with tetradentate Schiff bases," Journal of the Serbian Chemical Society, vol. 71, no. 8-9, pp. 917-928, 2006.

[24] M. Pandrala, F. Li, M. Feterl et al., "Chlorido-containing ruthenium(II) and iridium(III) complexes as antimicrobial agents," Dalton Transactions, vol. 42, no. 13, pp. 4686-4694, 2013.

[25] R. Bieda, I. Kitanovic, H. Alborzinia et al., "Antileukemic activity and cellular effects of rhodium(III) crown thiaether complexes," BioMetals, vol. 24, no. 4, pp. 645-661, 2011.

[26] S. Adhikari, O. Hussain, R. M. Phillips, and M. R. Kollipara, "Half-sandwich d 6 metal complexes comprising of 2substituted-1,8-napthyridine ligands with unexpected bonding modes: synthesis, structural and anti-cancer studies," Journal of Organometallic Chemistry, vol. 854, pp. 2737, 2018

[27] P. Štarha, Z. Trávniček, H. Crlikova, J. Vančo, J. Kašpárková, and Z. Dyořak, "Half-sandwich Ir(III) complex of N1-pyridyl-7-azaindole exceeds cytotoxicity of cisplatin at various human cancer cells and 3D multicellular tumor spheroids," Organometallics, vol. 37, no. 16, pp. 2749-2759, 2018.

[28] J. M. Hearn, I. Romero-Canelón, B. Qamar, Z. Liu, I. HandsPortman, and P. J. Sadler, "Organometallic iridium(III) anticancer complexes with new mechanisms of action: NCI60 screening, mitochondrial targeting, and apoptosis," ACS Chemical Biology, vol. 8, no. 6, pp. 1335-1343, 2013.

[29] D.-L. Ma, C. Wu, W. Tang et al., "Recent advances in iridium(III) complex-assisted nanomaterials for biological applications," Journal of Materials Chemistry B, vol. 6, no. 4, pp. 537-544, 2018.

[30] J. W. Arbiaster, "Is osmium always the densest metal? A comparison of the densities of iridium and osmium," 
Johnson Matthey Technology Review, vol. 58, no. 3, pp. 137-141, 2014.

[31] S. Czerczak and J. P. Gromier, Nickel, Ruthenium, Rhodium, Osmium, and Platinum, Wiley, Hoboken, NJ, USA, 2001.

[32] S. H. van Rijt, A. F. A. Peacock, and P. J. Sadler, "Osmium arenes: a new class of potential anti-cancer agents," in Platinum and Other Heavy Metal Compounds in Cancer Chemotherapy: Molecular Mechanisms and Clinical Applications. Cancer Drug Discovery and Development, pp. 73-79, Springer, Totowa, NJ, USA, 2009.

[33] W.-X. Ni, W.-L. Man, M. T.-W. Cheung et al., "Osmium(VI) complexes as a new class of potential anti-cancer agents," Chemical Communications, vol. 47, no. 7, pp. 2140-2142, 2011.

[34] S. H. Van Rijt, A. F. A. Peacock, R. D. L. Johnstone, S. Parsons, and P. J. Sadler, "Organometallic osmium(II) arene anticancer complexes containing picolinate derivatives," Inorganic Chemistry, vol. 48, no. 4, pp. 1753-1762, 2009.

[35] A. F. A. Peacock and P. J. Sadler, "Medicinal organometallic chemistry: designing metal arene complexes as anticancer agents," Chemistry-An Asian Journal, vol. 3, no. 11, pp. 1890-1899, 2008.

[36] I. N. Stepananko, G. E. Büchel, and B. K. Keppler, "Osmium complexes with azole heterocycles as potential antitumor drugs," Encyclopedia of Metalloproteins, pp. 1596-1614, 2013.

[37] Y. Fu, R. Soni, M. J. Romero et al., "Mirror-image organometallic osmium arene iminopyridine halido complexes exhibit similar potent anticancer activity," Chemistry-A European Journal, vol. 19, no. 45, pp. 15199-15209, 2013.

[38] H. K. Liu and P. J. Sadler, "Metal complexes as DNA intercalators," Accounts of Chemical Research, vol. 44, no. 5, pp. 349-359, 2011.

[39] H. Henke, W. Kandioller, M. Hanif, B. K. Keppler, and C. G. Hartinger, "Organometallic ruthenium and osmium compounds of pyridin-2- and -4-ones as potential anticancer agents," Chemistry \& Biodiversity, vol. 9, no. 9, pp. 1718-1727, 2012.

[40] A. M. Elsome, J. M. T. Hamilton-Miller, W. Brumfitt, and W. C. Noble, "Antimicrobial activities in vitro and in vivo of transition element complexes containing gold(I) and osmium(VI)," Journal of Antimicrobial Chemotherapy, vol. 37, no. 5, pp. 911-918, 1996.

[41] K. J. Kilpin, S. Crot, T. Riedel, J. A. Kitchen, and P. J. Dyson, "Ruthenium(ii) and osmium(ii) 1,2,3-triazolylidene organometallics: a preliminary investigation into the biological activity of "click" carbene complexes," Dalton Transactions, vol. 43, no. 3, pp. 1443-1448, 2014.

[42] B. K. Panda, "Synthesis, characterization and photophysical properties of quinolin-8-olato chelated osmium(II) organometallics bearing a pendant imine-phenol motif and electrogeneration of trivalent analogue," Open Journal of Inorganic Chemistry, vol. 2, no. 3, pp. 49-57, 2012.

[43] S. H. Van Rijt and P. J. Sadler, "Current applications and future potential for bioinorganic chemistry in the development of anticancer drugs," Drug Discovery Today, vol. 14, no. 23-24, pp. 1089-1097, 2009.

[44] P. Štarha, Z. Trávniček, J. Vančo, and Z. Dyořak, "Halfsandwich $\mathrm{Ru}(\mathrm{II})$ and $\mathrm{Os}(\mathrm{II})$ bathophenanthroline complexes containing a releasable dichoroacetato ligand," Molecules, vol. 23, no. 2, p. 420, 2018.

[45] Y. Fu, R. Soni, M. J. Romero et al., Mirror-Image Organometallic Osmium Arene Imunopyridine Halido Complexes
Exhibit Potent Anticancer Activity, Wiley, Hoboken, NJ, USA, 2013.

[46] I. Romero-Canelón, L. Salassa, and P. J. Sadler, "The contrasting activity of iodido versus chlorido ruthenium and osmium arene azo- and imino-pyridine anticancer complexes: control of cell selectivity, cross-resistance, p53 dependence, and apoptosis pathway," Journal of Medicinal Chemistry, vol. 56, no. 3, pp. 1291-1300, 2013.

[47] P. Zhang and P. J. Sadler, "Advances in the design of organometallic anticancer complexes," Journal of Organometallic Chemistry, vol. 839, pp. 5-14, 2017.

[48] P. Zhang and H. Huang, "Future potential of osmium complexes as anticancer drug candidates, photosensitizers and organelle-targeted probes," Dalton Transactions, vol. 47, no. 42, pp. 14841-14854, 2018.

[49] J. M. Gichumbi, H. B. Friedrich, B. Omondi, K. Naicker, M. Singh, and H. Y. Chenia, "Synthesis, characterization, antiproliferative, and antimicrobial activity of osmium(II) half-sandwich complexes," Journal of Coordination Chemistry, vol. 71, no. 2, pp. 342-354, 2018.

[50] W. P. Griffith, "Bicentenary of four platinum group metals Part 1: Rhodium and palladium-events surrounding their discoveries," Platinum Metals Review, vol. 48, no. 4, pp. 175-183, 2003.

[51] A. F. Elhusseiny and H. H. A. M. Hassan, "Antimicrobial and antitumor activity of platinum and palladium complexes of novel spherical aramides nanoparticles containing flexibilizing linkages: structure-property relationship," Spectrochimica Acta Part A: Molecular and Biomolecular Spectroscopy, vol. 103, pp. 232-245, 2013.

[52] A. S. Abu-Surrah, H. H. Al-Sa'doni, and M. Y. Abdalla, "Palladium-based chemotherapeutic agents: routes toward complexes with good antitumor activity," Cancer Therapy, vol. 6, pp. 1-10, 2008.

[53] E. Ulukaya, F. M. Frame, B. Cevatemre et al., "Differential cytotoxic activity of a novel palladium-based compound on prostate call lines, primary prostate epithelial cells and prostate stem cells," PLoS One, vol. 8, Article ID e64278, 2013.

[54] T. V. Serebryanskaya, T. Yung, A. A. Bogdanov et al., "Synthesis, characterization, and biological evaluation of new tetrazole-based platinum(II) and palladium(II) chlorido complexes-potent cisplatin analogues and their trans isomers," Journal of Inorganic Biochemistry, vol. 120, pp. 44-53, 2013.

[55] S. Ahmad, T. Rüffer, H. Lang et al., "Synthesis, crystal structure, and antimicrobial studies of trans- $\left[\mathrm{Pd}\left(\mathrm{PPh}_{3}\right)_{2}(\mathrm{i}-\right.$ midazolidine-2-thione $)_{2} \mathrm{CCl}_{2} \cdot 3.5 \mathrm{H}_{2} \mathrm{O}$," Russian Journal of Coordination Chemistry, vol. 36, no. 7, pp. 520-524, 2010.

[56] A. Bakalova, R. Buyukliev, G. Momekov, and D. Ivanov, "Synthesis and cytotoxic activity of new platinum and palladium complexes with 3-Amino- $\alpha$-Tetralonespiro- $5^{\prime}$ Hydantoin," Journal of Chemical Technology and Metallurgy, vol. 48, pp. 631-636, 2013.

[57] S. Ray, R. Mohan, J. K. Singh et al., "Anticancer and antimicrobial metallopharmaceutical agents based on palladium, gold, and silver N-heterocyclic carbene complexes," Journal of the American Chemical Society, vol. 129, no. 48, pp. 15042-15053, 2007.

[58] P. A. Ajibade and O. G. Idemudia, "Synthesis, characterization, and antibacterial studies of $\mathrm{Pd}(\mathrm{II})$ and $\mathrm{Pt}(\mathrm{II})$ complexes of some diaminopyrimidine derivatives," Bioinorganic Chemistry and Applications, vol. 2013, Article ID 549549, 8 pages, 2013. 
[59] B. Y. Wagbamare, D. D. Kumbhar, A. G. Pathade, and S. K. Pardeshi, "In-vitro antimicrobial activity of $\mathrm{Pd}(\mathrm{II})$ and $\mathrm{Ni}$ (II) chiral Schiff base ligand complexes," International Journal of Innovative Science Engineering and Technology, vol. 5, pp. 194-202, 2016.

[60] T. T. Fong, C. Lok, Y. E. Chung et al., Cyclometalated Palladium(II) N-Heterocyclic Carbene Complexes: Anticancer Agents for Potent in Vitro Cytotoxicity and in Vivo Tumor Growth Suppression, Wiley, Hoboken, NJ, USA, 2016.

[61] G. Pinto, "Antonio de Ulloa and the discovery of platinum: an opportunity to connect science and history through a postage stamp," Journal of Chemical Education, vol. 94, no. 7, pp. 970-975, 2017.

[62] L. B. Hunt, "Swedish contributions to the discovery of platinum the researchers of scheffer and bergman," Platinum Metals Review, vol. 24, pp. 31-39, 1980.

[63] J. Wisniak, "Platinum-from exotic to commodity," Indian Journal of Chemical Technology, vol. 12, pp. 601-614, 2005.

[64] R. A. Alderden, M. D. Hall, and T. W. Hambley, "The discovery and development of cisplatin," Journal of Chemical Education, vol. 83, no. 5, pp. 728-734, 2006.

[65] S. P. Fricker, "Metal based drugs: from serendipity to design,” Dalton Transactions, vol. 43, pp. 1-15, 2007.

[66] C. F. J. Barnard, "Platinum anti-cancer agents twenty years of continuing development," Platinum Metals Review, vol. 33, pp. 162-167, 1989.

[67] R. Lewis, "From basic research to cancer drug; the story of cisplatin," The Science, vol. 13, p. 11, 2009.

[68] J. J. Wilson and S. J. Lippard, "Synthetic methods for the preparation of platinum anticancer complexes," Chemical Reviews, vol. 114, no. 8, pp. 4470-4495, 2014.

[69] U. Ndagi, N. Mhlongo, and M. Soliman, "Metal complexes in cancer therapy \&ndash; an update from drug design perspective," Drug Design, Development and Therapy, vol. 11, pp. 599-616, 2017.

[70] T. C. Johnstone, J. J. Wilson, and S. J. Lippard, "Monofunctional and higher-valent platinum anticancer agents," Inorganic Chemistry, vol. 52, no. 21, pp. 12234-12249, 2013.

[71] B. Rosenberg, L. Van Camp, and T. Krigas, "Inhibition of cell division in Escherichia coli by electrolysis products from a platinum electrode," Nature, vol. 205, no. 4972, pp. 698-699, 1965.

[72] I. Kostova, "Platinum complexes as anticancer agents," Recent Patents on Anti-cancer Drug Discovery, vol. 1, no. 1, pp. 1-22, 2006.

[73] N. Manav, A. K. Mishra, and N. K. Kaushik, "In vitro antitumour and antibacterial studies of some $\mathrm{Pt}(\mathrm{IV})$ dithiocarbamate complexes," Spectrochimica Acta Part A: Molecular and Biomolecular Spectroscopy, vol. 65, no. 1, pp. 32-35, 2006.

[74] F. P. Andrew and P. A. Ajibade, "Synthesis, characterization and anticancer studies of bis(1-phenylpiperazine dithiocarbamato) $\mathrm{Cu}(\mathrm{II}), \mathrm{Zn}(\mathrm{II})$ and $\mathrm{Pt}(\mathrm{II})$ complexes: crystal structures of 1-phenylpiperazine dithiocarbamato-S, $\mathrm{S}^{\prime}$ zinc(II) and Pt(II)," Journal of Molecular Structure, vol. 1170, pp. 24-29, 2018.

[75] S. K. Bharti and S. K. Singh, "Recent development in the field of anticancer metallopharmaceuticals," International Journal of PharmTech Research, vol. 1, pp. 1406-1420, 2009.

[76] T. C. Johnstone, K. Suntharalingam, and S. J. Lippard, "The next generation of platinum drugs: targeted $\mathrm{Pt}(\mathrm{II})$ agents, nanoparticle delivery, and Pt(IV) prodrugs," Chemical Reviews, vol. 116, no. 5, pp. 3436-3486, 2016.
[77] P. a. Ma, H. Xiao, C. Li et al., "Inorganic nanocarriers for platinum drug delivery," Materials Today, vol. 18, no. 10, pp. 554-564, 2015.

[78] H. Xiao, H. Song, Q. Yang et al., "A prodrug strategy to deliver cisplatin(IV) and paclitaxel in nanomicelles to improve efficacy and tolerance," Biomaterials, vol. 33, no. 27, pp. 6507-6519, 2012.

[79] H. S. Oberoi, N. V. Nukolova, A. V. Kabanov, T. K. Bronich, and T. K. Bronich, "Nanocarriers for delivery of platinum anticancer drugs," Advanced Drug Delivery Reviews, vol. 65, no. 13-14, pp. 1667-1685, 2013.

[80] R. Mudiyanselage, G. Rajapakse, and S. P. Dunuweera, "Discovery, chemistry, anticancer action and targeting of cisplatin," International Journal of Clinical Oncology and Cancer Research, vol. 2, pp. 65-74, 2017.

[81] W. P. Griffith, "Bicentenary of four platinum group metals," Platinum Metals Review, vol. 48, no. 4, pp. 182-189, 2004.

[82] J. R. McConnell, D. P. Rananaware, D. M. Ramsey, K. N. Buys, M. L. Cole, and S. R. McAlpine, "A potential rhodium cancer therapy: studies of a cytotoxic organorhodium(I) complex that binds DNA," Bioorganic \& $\mathrm{Me}$ dicinal Chemistry Letters, vol. 23, no. 9, pp. 2527-2531, 2013.

[83] M. S. Jeremić, H. Wadepohl, V. V. Okoji et al., "Structural analysis, solution equilibria and biological activity of rhodium(III)," RSC Advances, vol. 7, no. 9, pp. 5282-5296, 2017.

[84] C. Parson, V. Smith, C. Krauss et al., "The effect of novel rhenium compounds on lymphosarcoma, PC-3 prostate and myeloid leukemia cancer cell lines and an investigation on the DNA binding properties of one of these compounds through electronic spectroscopy," Journal of Bioprocessing \& Biotechniques, vol. 4, no. 1, pp. 1-5, 2013.

[85] G. Gupta, A. Garci, B. S. Murray et al., "Synthesis, molecular structure, computational study and in vitro anticancer activity of dinuclear thiolato-bridged pentamethylcyclopentadienyl Rh(III) and Ir(III) complexes," Dalton Transactions, vol. 42, no. 43, pp. 15457-15463, 2013.

[86] C.-H. Leung, H.-J. Zhong, D. S.-H. Chan, and D.-L. Ma, "Bioactive iridium and rhodium complexes as therapeutic agents," Coordination Chemistry Reviews, vol. 257, no. 11-12, pp. 1764-1776, 2013.

[87] Y. Geldmacher, M. Oleszak, and W. S. Sheldrick, "Rhodium(III) and iridium(III) complexes as anticancer agents," Inorganica Chimica Acta, vol. 393, pp. 84-102, 2012.

[88] L. Oehninger, L. N. Küster, C. Schmidt, A. Muñoz-Castro, A. Prokop, and I. Ott, "A chemical-biological evaluation of rhodium(I)N-heterocyclic carbene complexes as prospective anticancer drugs," Chemistry-A European Journal, vol. 19, no. 52, pp. 17871-17880, 2013.

[89] J. Ruiz, V. Rodríguez, N. Cutillas et al., "Novel C,N-chelate rhodium(iii) and iridium(iii) antitumor complexes incorporating a lipophilic steroidal conjugate and their interaction with DNA," Dalton Transactions, vol. 41, no. 41, pp. 12847-12856, 2012.

[90] R. D. Gillard and E. Lekkas, "Complex compounds with rhodium(III) of enantiomers of nicotine," Transition Metal Chemistry, vol. 25, no. 6, pp. 617-621, 2000.

[91] M. A. Akbor, M. S. Islam, N. Akhter, S. Ahmed, and S. Siraj, "Studies on antibacterial and antifungal activities and minimum inhibitory concentrations of mixed ligand transition metal complexes of dibasic acids as primary and heterocyclic bases as secondary ligands," Bangladesh Journal of Scientific and Industrial Research, vol. 46, no. 3, pp. 365-368, 2011. 
[92] P. Chellan, K. M. Land, A. Shokar et al., "Di- and trinuclear ruthenium-, rhodium-, and iridium-functionalized pyridyl aromatic ethers: a new class of antiparasitic agents," Organometallics, vol. 32, no. 17, pp. 4793-4804, 2013.

[93] B. Desoize, "Metals and metal compounds in cancer treatment," Anticancer Research, vol. 24, pp. 1524-1544, 2004.

[94] Y. Geldmacher, M. Oleszak, and W. Sheldrick, "Rhodiu$\mathrm{m}(\mathrm{III})$ and iridium(III) as anticancer agents," Inorganica Chimica Acta, vol. 393, pp. 84-102, 2002.

[95] N. Katsaros and A. Anagnostopoulou, "Rhodium and its compounds as potential agents in cancer treatment," Critical Reviews in Oncology/Hematology, vol. 42, no. 3, pp. 297-308, 2002.

[96] A. R. Burgoyne, C. H. Kaschula, M. I. Parker, and G. S. Smith, "Tripodal half-sandwich rhodium and iridium complexes containing sulfonate and pyridinyl entities as antitumor agents," European Journal of Inorganic Chemistry, vol. 2017, no. 45, pp. 5379-5386, 2017.

[97] J. Markham, J. Liang, A. Levina et al., "(Pentamethylcyclopentadienato)rhodium complexes for delivery of the curcumin anticancer drug," European Journal of Inorganic Chemistry, vol. 2017, no. 12, pp. 1812-1823, 2017.

[98] A. Markowska, B. Kasprzak, K. Jaszczyńska-Nowinka, J. Lubin, and J. Markowska, "Noble metals in oncology," Współczesna Onkologia, vol. 4, pp. 271-275, 2015.

[99] R. E. Sioda, "Vestium or ruthenium-what does a study of the literature tell us?," CHIMIA International Journal for Chemistry, vol. 65, no. 6, pp. 429-432, 2011.

[100] G. B. Kauffman, J. L. Marshall, and V. R. Marshal, "Karl Karlovich Klaus (1796-1864) and the discovery of ruthenium," The Chemical Educator, vol. 19, pp. 105-106, 2014.

[101] K. Buldurun, N. Turan, I. Savei, and N. Çolak, "Synthesis, structural characterization and biological activities of metal(II) complexes with Schiff bases derived from 5-bromosalicylaldehyde: $\mathrm{Ru}(\mathrm{II})$ complexes transfer hydrogenation," Journal of Saudi Chemical Society, vol. 23, no. 2, pp. 205-214, 2018.

[102] A. A. Nazarov, C. G. Hartinger, and P. J. Dyson, "Opening the lid on piano-stool complexes: an account of ruthenium(II)-arene complexes with medicinal applications," Journal of Organometallic Chemistry, vol. 751, pp. 251-260, 2014.

[103] C. S. Allardyce and P. J. Dyson, "Ruthenium in medicine: current clinical uses and future prospects," Platinum Metals Review, vol. 45, pp. 62-69, 2001.

[104] I. Bratsos, S. Jedner, T. Gianferrara, and E. Alessio, "Ruthenium anticancer compounds: challenges and expectations," CHIMIA International Journal for Chemistry, vol. 61, no. 11, pp. 692-697, 2007.

[105] I. Kostova, "Ruthenium complexes as anticancer agents," Current Medicinal Chemistry, vol. 13, no. 9, pp. 1085-1107, 2006.

[106] A. R. Sharma, D. M. Gangrade, S. D. Bakshi, and J. S. John, "Ruthenium complexes:-potential candidate for anti-tumour activity," International Journal of Chem Tech Research, vol. 6, pp. 828-837, 2014.

[107] T. Laxmi, K. Praveen, and A. K. Singhai, "Role of chelates in treatment of cancer," Indian Journal of Cancer, vol. 44, no. 2, pp. 62-71, 2007.

[108] J. Ruiz, C. Vicente, C. de Haro, and D. Bautista, "A novel ruthenium(II) arene based intercalator with potent anticancer activity," Dalton Transactions, no. 26, pp. 5071-5073, 2009.
[109] K. N. Kumar, A. Bhimareddy, and N. Naik, "ChemInform abstract: ruthenium metal complexes and their biological approach-a short review," IJPSR, vol. 5, pp. 758-773, 2014.

[110] W. H. Ang and P. J. Dyson, "Classical and non-classical ruthenium-based anticancer drugs: towards targeted chemotherapy," European Journal of Inorganic Chemistry, vol. 2006, no. 20, pp. 4003-4018, 2006.

[111] R. Santamaria, C. Irace, G. D’Errico, D. Montesarchio, and L. Paduano, "Perspectives and potential applications of ruthenium-based nanocarriers for cancer therapy," Journal of Pharmaceutics and Drug Development, vol. 1, no. 2, pp. 1-4, 2013.

[112] M. Gobec, J. Kljun, I. Sosič et al., "Structural characterization and biological evaluation of a clioquinol-ruthenium complex with copper-independent antileukaemic activity," Dalton Transactions, vol. 43, no. 24, pp. 9045-9051, 2014.

[113] I. Warad, A. F. Eftaiha, M. A. Al-Nuri et al., "Metal ions as antitumour complexes-review," Journal of Materials and Environmental Science, vol. 4, pp. 542-557, 2013.

[114] I. Turel, J. Kljun, F. Perdih et al., "First ruthenium organometallic complex of antibacterial agent ofloxacin. Crystal structure and interactions with DNA," Inorganic Chemistry, vol. 49, no. 23, pp. 10750-10752, 2010.

[115] M. Kiruthika, R. Elayaperumal, and T. Vennila, "Synthesis and antifungal potential of a ruthenium (II) complex," Der Chemica Sinica, vol. 3, pp. 1175-1180, 2012.

[116] K. S. Prasad, L. S. Kumar, H. D. Revanasiddappa, B. Vijay, and B. Jayalakshmi, "Synthesis, characterization and antimicrobial activity of $\mathrm{Cu}(\mathrm{II}), \mathrm{Co}(\mathrm{II}), \mathrm{Ni}(\mathrm{II}), \mathrm{Pd}(\mathrm{II})$ and $\mathrm{Ru}(\mathrm{III})$ complexes with clomiphene citrate," Chemical Sciences Journal, vol. 2, pp. 1-11, 2011.

[117] F. Li, M. Feterl, Y. Mulyana, J. M. Warner, J. G. Collins, and F. R. Keene, "In vitro susceptibility and cellular uptake for a new class of antimicrobial agents: dinuclear ruthenium(II) complexes," Journal of Antimicrobial Chemotherapy, vol. 67, no. 11, pp. 2686-2695, 2012.

[118] S. Thota, S. S. Karki, and B. R. Bhukya, "Synthesis, characterization and antibacterial activity of some mononuclear $\mathrm{Ru}(\mathrm{II})$ complexes," International Journal of Pharmacy and Pharmaceutical Sciences, vol. 1, pp. 62-70, 2009.

[119] A. A. Adeniyi and P. A. Ajibade, "The anticancer activities of some nitrogen donor ligands containing bis-pyrazole, bipyridine, and phenanthroline moiety using docking methods," Bioinorganic Chemistry and Applications, vol. 2018, Article ID 5796287, 12 pages, 2018.

[120] I. P. Ejidike and P. A. Ajibade, "Synthesis, characterization, anticancer, and antioxidant studies of $\mathrm{Ru}(\mathrm{III})$ complexes of monobasic tridentate Schiff bases," Bioinorganic Chemistry and Applications, vol. 2016, Article ID 9672451, 11 pages, 2016.

[121] I. P. Ejidike and P. A. Ajibade, "Synthesis, characterization, andin vitroantioxidant and anticancer studies of ruthenium(III) complexes of symmetric and asymmetric tetradentate Schiff bases," Journal of Coordination Chemistry, vol. 68, no. 14, pp. 2552-2564, 2015.

[122] W. M. Motswainyana and P. A. Ajibade, "Anticancer activities of mononuclear ruthenium(II) coordination complexes," Advances in Chemistry, vol. 2015, Article ID 859730, 21 pages, 2015.

[123] A. A. Adeniyi and P. A. Ajibade, "The spectroscopic and conductive properties of $\mathrm{Ru}(\mathrm{II})$ complexes with potential anticancer properties," Journal of Spectroscopy, vol. 2014, Article ID 656830, 14 pages, 2014. 
[124] C. Scolaro, A. B. Chaplin, C. G. Hartinger et al., "Tuning the hydrophobicity of ruthenium(ii)-arene (RAPTA) drugs to modify uptake, biomolecular interactions and efficacy," Dalton Transactions, vol. 43, pp. 5065-5072, 2007.

[125] P. Govender, N. C. Antonels, J. Mattsson et al., "Anticancer activity of multinuclear arene ruthenium complexes coordinated to dendritic polypyridyl scaffolds," Journal of Organometallic Chemistry, vol. 694, no. 21, pp. 3470-3476, 2009.

[126] G. Suss-Fink, "Arene ruthenium complexes as anticancer agents," Dalton Transactions, vol. 39, pp. 1673-1688, 2010.

[127] B. S. Murray, L. Menin, R. Scopelliti, and P. J. Dyson, "Conformational control of anticancer activity: the application of arene-linked dinuclear ruthenium(II) organometallics," Chemical Science, vol. 5, no. 6, pp. 2536-2545, 2014.

[128] A. A. Adeniyi and P. A. Ajibade, "Theoretical study of interatomic properties of ruthenium half-sandwich anticancer complexes containing Ru-N bonds," Asian Journal of Chemistry, vol. 27, no. 3, pp. 907-918, 2015.

[129] G. Ludwig, M. Mojić, M. Bulatović et al., "Biological potential of half sandwich ruthenium(II) and iridium(III) complexes," Anti-Cancer Agents in Medicinal Chemistry, vol. 16, pp. 1455-1460, 2016.

[130] J. Li, M. Tian, Z. Tian et al., "Half-sandwich iridium(III) and ruthenium(II) complexes containing PP-chelating ligands: a new class of potent anticancer agents with unusual redox features," Inorganic Chemistry, vol. 57, no. 4, pp. 1705-1716, 2018.

[131] M. Carmona, R. Rodríguez, F. J. Lahoz et al., "Half-sandwich complexes of iridium and ruthenium containing cysteinederived ligands," Dalton Transactions, vol. 46, no. 3, pp. 962-976, 2017.

[132] J. Téllez, A. Gallen, J. Ferrer et al., "Half-sandwich complexes of $\operatorname{Ir}(\mathrm{III}), \mathrm{Rh}(\mathrm{III})$ and $\mathrm{Ru}(\mathrm{II})$ with the MaxPhos ligand: metal centred chirality and cyclometallation," Dalton Transactions, vol. 46, no. 45, pp. 15865-15874, 2017.

[133] L. Zeng, P. Gupta, Y. Chen et al., "The development of anticancer ruthenium(II) complexes: from single molecule compounds to nanomaterials," Chemical Society Reviews, vol. 46, no. 19, pp. 5771-5804, 2017. 

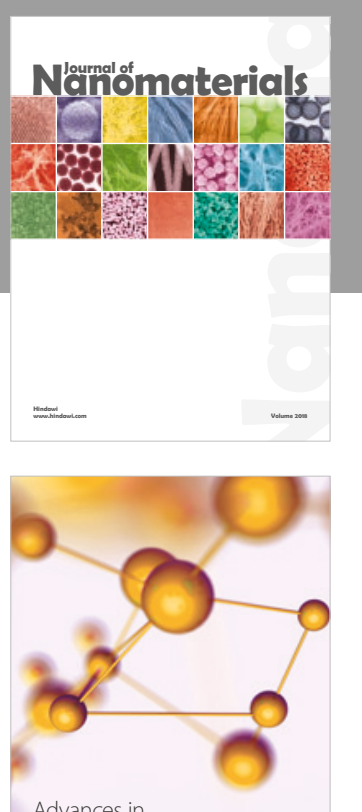

Physical Chemistry
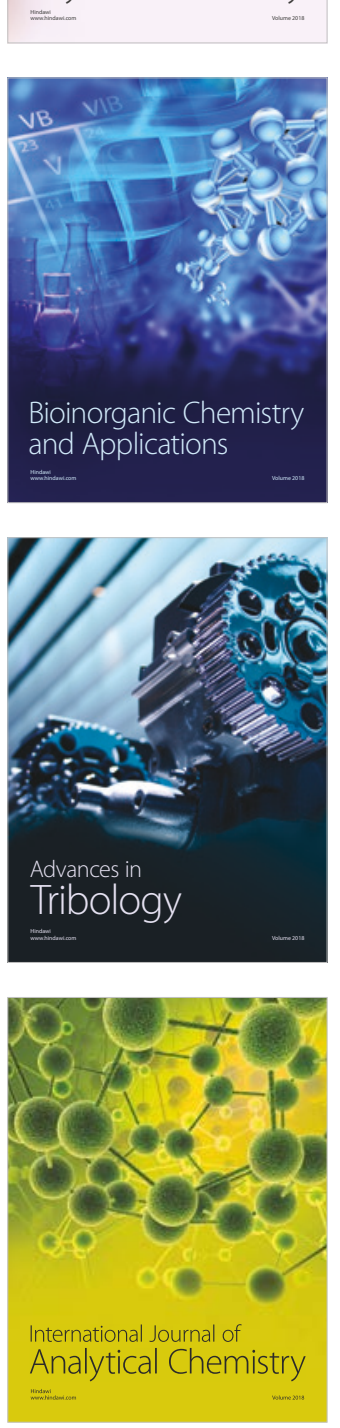

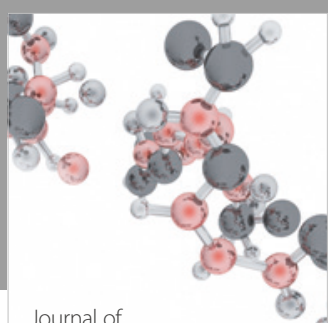

Analytical Methods

in Chemistry

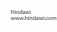

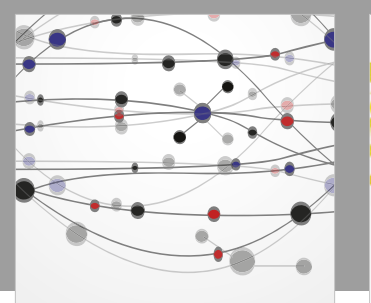

The Scientific World Journal

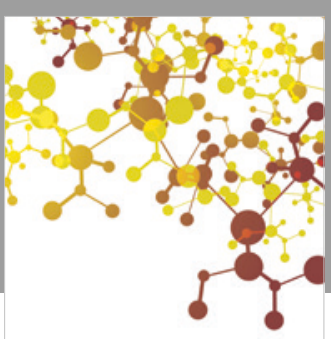

Journal of

Applied Chemistry
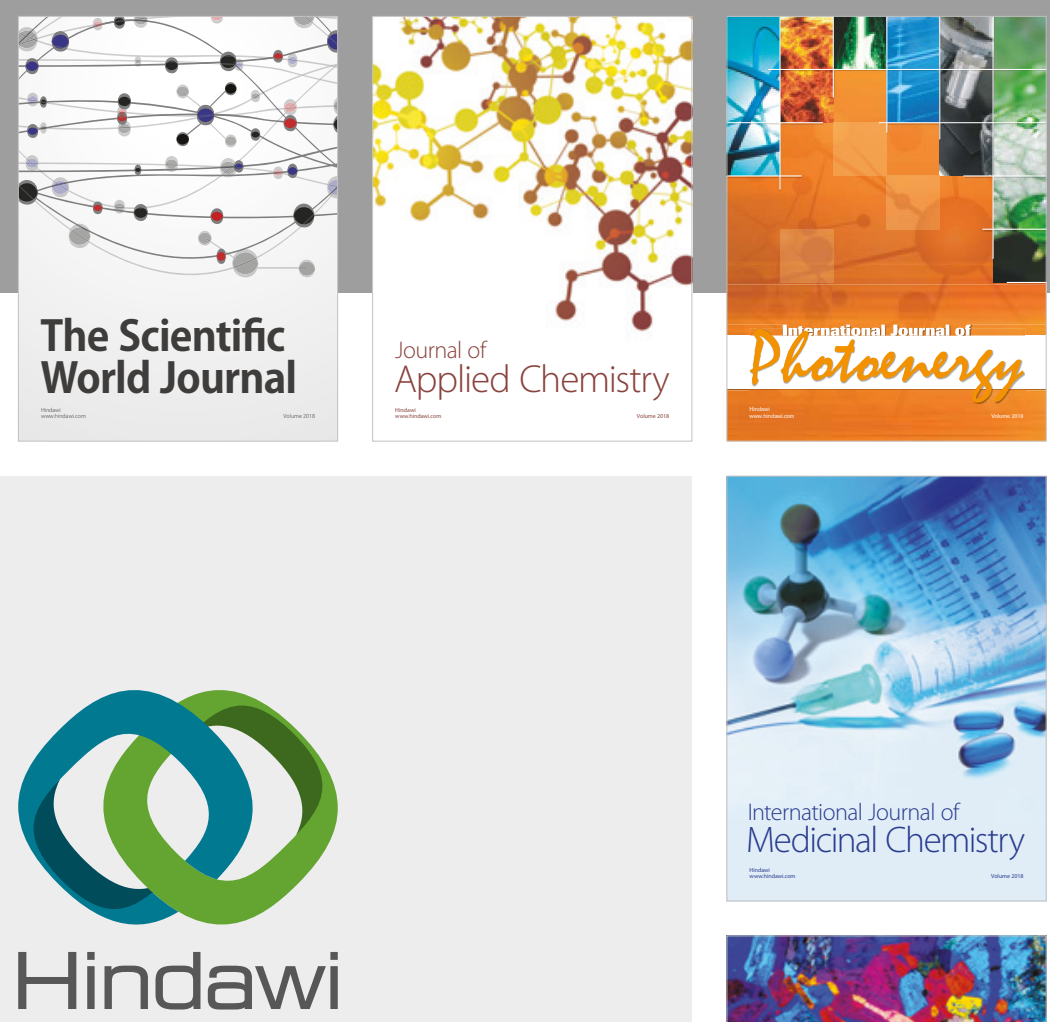

Submit your manuscripts at

www.hindawi.com
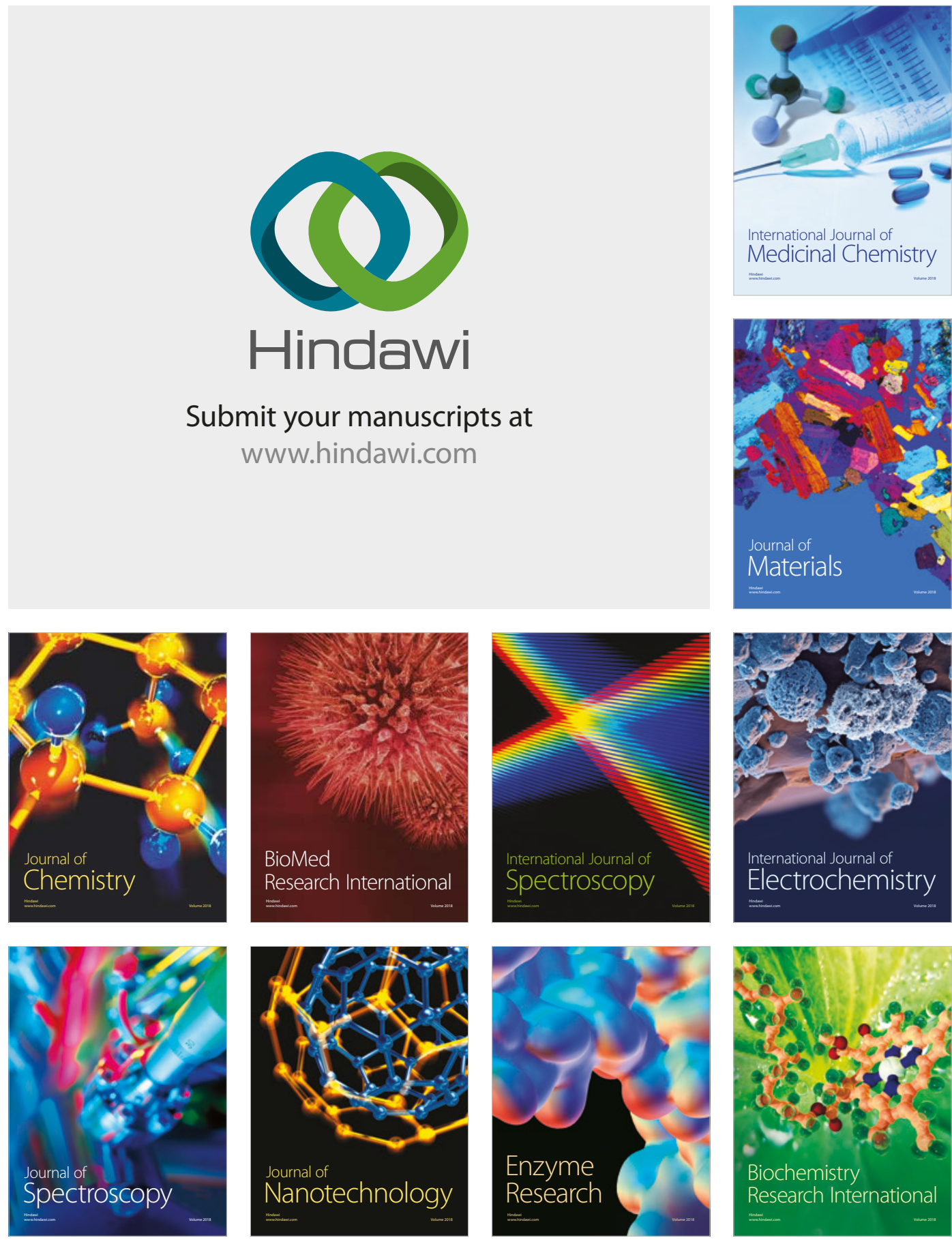
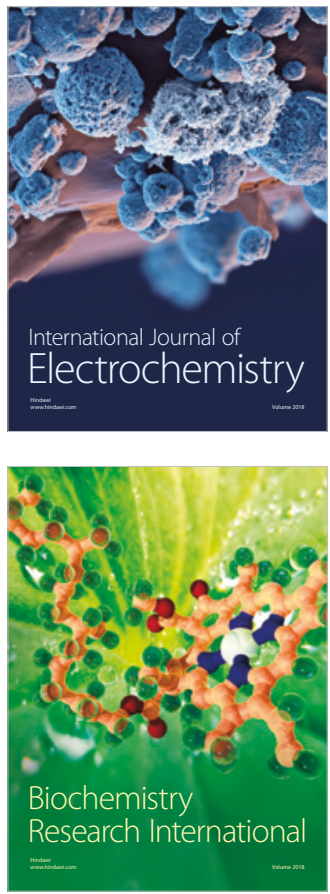